\title{
Nekonečný příběh Nejvyšší rady soudnictví: Kdo ji chce a proč ji pořád nemáme?*
}

\section{The Neverending Story of the Council for the Judiciary: Who Wants It and Why We Do Not Have It?}

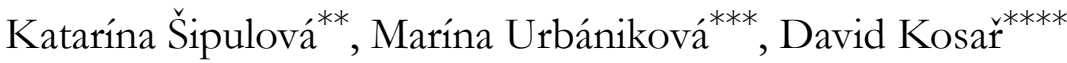

\begin{abstract}
Abstrakt
I presto, že diskuse o Nejvyššr radě soudnictvi (NRS) trvá už několik dekád, komplexní analyza toho, jaké postoje ke zrízeni NRS zastávaji klićovi aktérí, kterých se samospráva soudnictvi týká - soudci, politici a praktikujici právnici - doposud chybi. Cílem tohoto textu je tuto mezeru vyplnit a na základè rozhovoru se zástupci českých prárnických, soudcovských a politických elit żmapovat argumenty, keteré rozdèluji zastánce a odpuirce NRS. V článku si klademe tri blavni otázky: 1) Jak se zástupci právnických, soudcovských a politických elit stavi ke zrízeni NRS a jakými argumenty svou pozici zdivvodñuji? 2) Jakou by mèla mit správa soudnictvi podle nich ideální podobu? 3) Co tyto trí skupiny od v₹niku NRS očekávaji?

Hlavni zjišténi jsou následujici. Soudci, politici a právnici identifikovali stejné dva klićové problémy stávajicíbo systému: ministerstvo nemá kapacitu ani vizi, jak soudnictvi spravovat, a mnobé kompetence proto deleguje na prédsedy soudi. Príliš silné postaveni predsedi soudù však vede ke fragmentaci správy

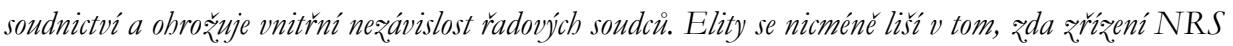
tyto problémy vyrešs. Vètšina soudcu v₹nik NRS podporuje a očekává od ni sjednoceni správy soudnictví a odbremenèni prèdsedu soudu. Cást politikè by soublasila s ustanovenim slabébo modelu NRS, pokud by kontury systému porád nastavovalo ministerstvo spravedlnosti. Zároveň však tvrdí, že fragmentovaná správa je lepši zárukou proti ovládnuti soudnictvi jednou skupinou. Právnici pak vidí v zrízeni NRS

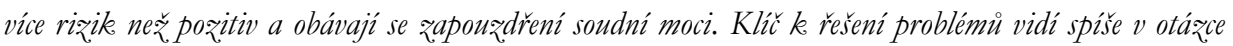
právnickébo vądèláváni a zuýšeni kvality soudního roz̧odováni. Současné debaty o správě soudnictví ani posledni novely zákona o soudech a soudcich však bohuřel na tyto klícové problémy identifikované respondenty dosud nereagovaly.
\end{abstract}

* Výzkum, který vedl $\mathrm{k}$ tomuto článku, byl financován prostředky Evropské výzkumné rady v rámci programu Evropské unie pro výzkum a inovace 2020 (grant no. 678375 JUDI-ARCH ERC-2015-STG).

** Mgr. et Mgr. Katarína Šipulová, Ph.D., M.St., Ústav pro otázky soudnictví (JUSTIN), Právnická fakulta, Masarykova univerzita, Brno / JUSTIN - Judicial Studies Institute, Faculty of Law, Masaryk University, Brno, Czech Republic / E-mail: katarina.sipulova@law.muni.cz / ORCID: 0000-0002-3593-3594

*** Mgr. et Mgr. Marína Urbániková, Ph.D., odborná asistentka, Katedra mediálních studí́ a žurnalistiky, Fakulta sociálních studií, Masarykova univerzita, Brno; Ústav pro otázky soudnictví (JUSTIN), Právnická fakulta, Masarykova univerzita, Brno / Assistant Professors, Department of Media Studies and Journalism, Faculty of Social Studies, Masaryk University, Brno, Czech Republic; JUSTIN - Judicial Studies Institute, Faculty of Law, Masaryk University, Brno, Czech Republic / E-mail: urbaniko@fss. muni.cz / ORCID: 0000-0003-1640-9823

**** Doc. JUDr. David Kosař, Ph.D., LL.M., J. S. D., vedoucí, Ústav pro otázky soudnictví (JUSTIN), Právnická fakulta, Masarykova univerzita, Brno / head, JUSTIN - Judicial Studies Institute, Faculty of Law, Masaryk University, Brno, Czech Republic / E-mail: david.kosar@law.muni.cz / ORCID: 0000-0001-5025-1367 


\title{
Klíčová slova
}

Soudnictví; Nejvy šsi rada soudnictví; soudcouská samospráva.

\begin{abstract}
Establishment of the judicial council has been debated for decades in Czechia. However, we still miss a comprehensive understanding of the positions and arguments of key actors involved in judicial governance: judges, politicians and lanyers. This article fills this gap and maps the existing arguments in favour and against a judicial council. It poses three research questions: (1) Do elites support the establishment of a judicial council and how do they justify their position? (2) What form of judicial governance do they perceive as ideal? (3) What are their expectations from the judicial council?

Judges, politicians and lawyers identify the same two core challenges of the current system: The ministry of justice lacks the vision and capacity to govern the courts, and thus it informally delegates majority of its competences on court presidents. Too strong court presidents in turn make the system fragmented and endanger internal independence of rank-and-file judges. Elites however disagree whether the establishment of a judicial council can solve these issues. Majority of judges support the judicial council and hope for the unification of judicial governance across the country. Some politicians are willing to accept a weak model of judicial council if the ministry of justice can still determine the contours of judicial governance. At the same time, politicians consider the current fragmented system of judicial governance as more resistant against the capture of the judiciary. Lanyers see judicial council as a risky model which might encapsulate the judiciary. The key solution of the current problems, according to lanyers, rests in the reform of legal education and enbancing the quality of the judicial decision-making. Unfortunately, the neither recent policy debates nor the pending bills on the Law on Courts and Judges have addressed the key challenges raised by our interviewees.
\end{abstract}

\section{Keywords}

Judicial Governance; Judicial Council; Courts; Judges; Ministry of Justice; Court Presidents; Separation of Powers; Judicial Politics.

\section{Úvod}

Od prvního pokusu tehdejšího ministra spravedlnosti Otakara Motejla o ustanovení Nejvyšší rady soudnictví (dále též „NRS“) uplynulo již přes 20 let. Motejlův návrh na posílení soudcovské samosprávy ${ }^{1}$ neprošel. Od té doby žádný návrh Nejvyšší rady soudnictví nepostoupil tak daleko, aby se dostal v paragrafovaném znění do parlamentu. Debata o reformě správy soudnictví však neutichla. Zejména představitelé justice, včetně obou nejvyšších obecných soudů, totiž vytrvale volají po vytvoření „reprezentativního orgánu“, který by „dlouhodobě, efektivně, kontinuálně a kompetentně zajištoval chod státni správy soudnictví a vytvoril institucionalizované prostredípro kontakt s veřejností i s dalšimi složkami moci“.2

1 Pojem „soudcovská samospráva“ považujeme za nepřesný termín a souhlasíme s Janem Kyselou, že ,"v diskusich o správě soudnictvi nejde o samosprávu', nýbrž o správu s podílem soudcü“ (srov. KYSELA, Jan. Na okraj debat o modelu správy soudnictví v České republice. In: KYSELA, Jan (ed.). Hledání optimálního modelu správy soudnictví pro Ceskou republiku. Praha: Kancelár Senátu, 2008, s. 156). Pojem „soudcovská samospráva“ se však v českém i zahraničním právním diskurzu natolik usadil, že si jej dovolíme používat i v tomto článku.

2 Zelená kniha justice. Nejvy̌š̌i soud [online]. Dostupné z: http://www.nsoud.cz/Judikatura/ns_web.nsf/ Zelen $\%$ C3\%A1\%20kniha\%20justice.pdf 
Česká justice rozhodně není ve volání po emancipaci osamocená. Judicializace, rostoucí vliv soudů a politický vývoj po pádu železné opony zvýšil poptávku po zárukách soudcovské nezávislosti, v jejímž jádru stojí odstínění vlivu exekutivy na výběr a kariérní postup soudců. ${ }^{3}$ Ve stř̌ední a východní Evropě se po roce 1989 výrazem tohoto odstínění stalo zrrizování nejvyšších rad soudnictví. Chvíli se zdálo, že akademická i politická sféra nalezly vzácný konsenzus na nejvhodnějším modelu správy soudnictví, který by zajistil dostatečnou nezávislost soudců na vnitřních i vnějších politických vlivech. ${ }^{5}$ Silnou NRS jako jediný vhodný model správy soudnictví svorně doporučovala i řada mezinárodních institucí a Evropská komise $\mathrm{v}$ prrístupovém procesu. $\mathrm{V}$ posledních letech se $\mathrm{k}$ nim přidaly i oba evropské nadnárodní soudy, Evropský soud pro lidská práva ${ }^{7}$ a Soudní dvůr Evropské unie. ${ }^{8}$

Za posledních pět let se však mnohé změnilo. Populistické útoky na soudní nezávislost v Polsku a Mad'arsku, politizace soudnictví probíhající v Rumunsku, Turecku či na Ukrajině, jakož i rozkrytí hluboké korupční sítě uvnitř slovenské justice potvrdily, že politici, kteří usilují o ovládnutí soudní moci, mají eminentní zájem získat kontrolu nad výběrem soudců a složením vrcholných soudů. Tyto útoky rovněž ukázaly, že NRS jsou křehkými orgány, jež bez podpory právního státu ze strany odborné a širší veřejnosti nedokážou politizaci samy odolat. Svým způsobem se tak potvrdily obavy vznesené již dříve řadou akademiků,

3 GINSBURG, Tom a Nuno GAROUPA. Guarding the Guardians: Judicial Councils and Judicial Independence. The American Journal of Comparative Law, 2009, roč. 57, č. 1; A také EPSTEIN, Richard. The Independence of Judges: The Uses and Limitations of Public Choice. Brigham Young University Law Review, 1990, č. 827; LANDES, William a Richard POSNER. The Independent Judiciary in an InterestGroup Perspective. Journal of Law and Economics, 1975, roč. 18, č. 3, s. 875-901; MALLESON, Kate a Peter RUSSELL (eds.). Appointing Judges in an Age of Judicial Power: Critical Perspectives from around the World. Toronto: University of Toronto Press, 2006, $450 \mathrm{~s}$.

4 NRS se ale po vzoru Itálie a Francie hojně šírily také v zemích Latinské Ameriky. Srov. i BEERS, Daniel. Judicial Self-Governance and the Rule of Law. Problems of Post-Communism., 2012, roč. 59, č. 5, s. 50-67.

5 RENOUX, Thierry-Serge. Les Conseils superieurs de la magistrature en Europe. La Documentation Française, 1999, 319 s.; GUARNIERI, Carlo Guarnieri a Patrizia PEDORZOLI. The Power of Judges: A Comparative Study of Courts and Democracy. Oxford: Oxford University Press, 2002, 248 s.; VOERMANS, Wim Voermans a Pim ALBERS. Councils for the Judiciary in EU Countries. Štrasburk: European Commission for the Efficiency of Justice, CEPEJ, 2003, 129 s.; AUTHERMAN, Violaine a Sandra ELENA. Global Best Practices: Judicial Councils: Lessons Learned from Europe and Latin America. IFES Rule of Law White Paper Series [online]. 2004, č. 2 [cit. 15. 1. 2021]. Dostupné z: https://www.csm.org.pt/wp-content/ uploads/2017/12/authemaandelena2004judicialcouncilslessonslearnedeuropelatinamerica.pdf

6 Srov. Organization for the Security and Cooperation in Europe (dostupné z: https://jobs.osce. org/vacancies/expert-judicial-self-governance-vnodic00667), the European Committee on Legal Co-operation (dostupné z: https://www.coe.int/en/web/cdcj/co-operation-projects/judicial-self-governance-trainingazerbaijan); a International Commission of Jurists (dostupné z: https://www.icj. org/new-icj-report-analyses-thetransition-to-judicial-self-governance-in-serbia).

7 Srov. rozsudek Evropského soudu pro lidská práva ze dne 25. záŕí 2018, Denisov vs. Ukrajina, č. 76639/11; a rozsudek Evropského soudu pro lidská práva ze dne 6. listopadu 2018, ve spojených věcech Ramos Nunes de Carvalho e Sá vs. Portugalsko, č. 55391/13, 57728/13 and 74041/13.

8 Srov. rozsudek Soudního dvora Evropské unie ze dne 25. července 2018, Minister for Justice and Equality vs. $L M$, věc C-216/18 PPU; a rozsudek Soudního dvora Evropské unie ze dne 24. června 2019, Evropská komise vs. Polská republika, věc C-619/18. 
kteří upozorňovali, že mezi NRS a úrovní soudcovské nezávislosti či dokonce efektivity soudního rozhodování existuje přinejlepším jen velmi nepř́ímý vztah. ${ }^{9}$

$\mathrm{V}$ české debatě prozatím hlubší reflexe role NRS ve srovnání s jinými modely soudcovské (samo)správy chybí. ${ }^{10} \mathrm{Na}$ první pohled se zdá, že český diskurz se dostal do patové situace, nebot' justice volá po zrrízení NRS coby výrazu své nezávislosti, zatímco politici projevují nevoli toto volání vyslyšet. Ve skutečnosti nám však hlubší porozumění postojům a argumentům obou skupin chybí. Relativně dobře známé jsou pouze medializované názory justičních špiček ${ }^{11}$ a vybraných ministrů spravedlnosti. ${ }^{12}$ Zcela však absentují hlasy řadových soudců okresních a krajských soudů, kterých by se proměna modelu správy soudnictví dotkla možná nejvíce. Ještě útržkovitější informace máme o postojích politiků a praktikujících právníků. Stejně tak v debatě chybí i hlubší analýza důvodů, které jednotlivé aktéry vedou k podpoře či odmítání NRS.

9 GINSBURG, GAROUPA, supra n. 4; BOBEK, Michal a David KOSAŘ. Global Solutions, Local Damages: A Critical Study in Judicial Councils in Central and Eastern Europe. German Law Journal, 2014, roč. 15, č. 7, s. 1257-1292; VOIGT, Stefan. Determinants of judicial efficiency: a survey. European Journal of Law and Economics, 2016, roč. 42, s. 183-208; SMILOV, Daniel. EU Enlargement and the Constitutional Principle of Judicial Independence. In: CZARNOTA, Adam, Martin KRYGIER a Wojciech SADURSKI (eds.). Spreading Democracy and the Rule of Law: The Impact of EU Enlargement on the Rule of Law, Democracy, and Constitutionalism in Post-Communist Legal Orders. Dordrecht: Springer, 2006, s. 323-325; POPOVA, Maria. Can a leopard change its spots? Strategic behavior versus professional role conception during Ukraine's 2014 court chair elections. Law \& Politics, 2020, roč. 42, č. 4, s. 365-381.

10 Pro výjimky srov. např. KOSAŘ, David. Judicializace justični politiky Evropským soudem pro lidská práva. Praha: Wolters Kluwer, 2017, 295 s.; KYSELA, 2008, supra n. 1; nebo ŠÁMAL, Pavel a Katarína DEÁKOVÁ. Teoretické a praktické aspekty spojené se správou justice. Časopis pro právní vědu a praxi, 2017 , roč. 15 , č. 3 , s. $521-543$.

11 Srov. interní dokument k návrhu NRS, který Lidovým novinám poskytl Josef Baxa: Nejvyšší správní soud. Interní pracovní text k možné úpravě Nejvyšší rady soudnictví („NRS“) na úrovni Ústavy a podústavnî roviny (leden 2013). Lidovky [online]. 2013 [cit. 15.1.2021]. Dostupné z: https://www.lidovky.cz/galeriedokumentu.aspx?dg=237; KRAMER, Jaroslav. Nejvyšší soudci Baxa a Šámal chtějí radu soudnictví. Došla nám trpělivost, říkají. Hospodáršké noviny [online]. 2. 11. 2015 [cit. 15. 1. 2021]. Dostupné z: https:// archiv.ihned.cz/c1-64805730-nejvyssi-soudci-baxa-a-samal-chteji-radu-soudnictvi-dosla-nam-trpelivost-rikaji; SCHABU, Martin. Iva Brožová: Problémem soudů není rychlost... Česká pozuice [online], 20. 2. 2015 [cit. 15.1.2021]. Dostupné z: https://ceskapozice.lidovky.cz/tema/iva-brozova-problemem-neni-rychlost-ale-duveryhodnost-soudu.A150217_145438_pozice-tema_kasa; Česká televize. Soudci chtějí reprezentační radu, Šámal připouští i vliv politiků. CT24 [online]. 25. 1. 2015 [cit. 15.1.2021]. Dostupné z: https://ct24.ceskatelevize.cz/domaci/1496682-soudci-chteji-reprezentacni-radu-samal-pripousti-i-vliv-politiku; Aktuálně.cz. Rychetský: Nemůžeme žít s předpisy ze 60. let. Nutné jsou komory, aby se odborníkem nestal neumětel. Aktuálně.cz [online]. 11. července 2018 [cit. 15.1.2021]. Dostupné z: https://zpravy.aktualne.cz/domaci/rychetsky-nemuzeme-zit-s-predpisy-ze-60-let-nutne-jsou-komor/ r 441a492a84d811e8a6210cc47ab5f122/

12 ŠTEFAN, Václav. Vznik Nejvyšší rady soudnictví by mohl vést k zakonzervování justice, myslí si ministr. Unie to odmítá. iRoz̧blas.cz [online]. 21. 10. 2018 [cit. 15.1.2021]. Dostupné z: https://www.irozhlas. cz/zpravy-domov/nejvyssi-rada-soudnictvi-jan-knezinek_1810211918_pj; KRAMER, Jaroslav. Ministr Pelikán chce snížit počet exekutorů. Nejvyšší radě soudnictví se nebrání. Hospodárskeé noviny [online]. 12. 11. 2015 [cit. 15.1.2021]. Dostupné z: https://domaci.ihned.cz/c1-64855520-ministr-pelikan-chce-snizit-pocet-exekutoru-nejvyssi-rade-soudnictvi-se-nebrani; Premiér podporuje vznik Nejvyšší rady soudnictví. Vláda Ceské republiky [online]. 21. 7. 2011 [cit. 15. 1. 2021]. Dostupné z: https://www.vlada. $\mathrm{cz} /$ scripts $/$ detail.php?id $=86226 \&$ tmplid $=50$ 
Náš článek má za cíl tuto mezeru v debatě o zřízení NRS vyplnit. Na základě rozhovorů se zástupci českých právnických a politických elit mapuje argumenty, které rozdělují zastánce a odpůrce NRS. V článku si klademe tři klíčové otázky: 1) Jak se zástupci soudcovských, právnických a politických elit staví ke zř́zení NRS a jakými argumenty svou pozici zdůvodňují? 2) Jakou by měla mít správa soudnictví podle nich ideální podobu? 3) Co tyto tři skupiny od vzniku NRS očekávají?

Za účelem zodpovězení těchto otázek jsme oslovili tři skupiny aktérů - vysoce postavené politiky, soudce a právníky. Logika výběru právě těchto tři skupin byla následující. Soudci reprezentují skupinu, které se správa soudnictví bezprostředně týká. Politici zastupují elitu, která tvoří legislativní rámec správy soudnictví a následně správu soudnictví skrze ministerstvo spravedlnosti i realizují. Praktikující právníci a zejména advokáti pak představují uživatele systému, nebot' zastupují klienty soudního systému. ${ }^{13}$ Rozšířením respondentů nad rámec představitelů justice se lišíme od většiny českých i zahraničních výzkumů, ${ }^{14}$ jež se zaměřují výhradně na soudce. Tím získáváme širší společenský náhled na fungování správy soudnictví v České republice a na NRS. Zapojení politiků a právníků zároveň slouží jako pojistka proti př́liš soudcocentrickému pohledu na správu soudnictví.

Celkem jsme hovořili s 27 respondenty. Šlo o špičkové reprezentanty soudů (včetně tehdejších a bývalých soudních funkcionářo̊); představitele významných pražských i regionálních advokátních kanceláří (včetně tehdejších a bývalých zástupců vedení České advokátní komory), právníky se zkušenostmi ve vedoucích pozicích ve státním zastupitelství a akademiky věnující se soudnictví; a též o tehdejší a bývalé ministry spravedlnosti a klíčové představitele největších politických stran, kteří se specializují na oblast justice. ${ }^{15}$

13 Podmínkou začlenění osoby mezi respondenty jedné ze tři skupin bylo angažování se v problematice (samo)správy soudnictví. Zejména $\mathrm{v}$ případě politiků jsme proto volili pouze osoby, které se přímo podílely na rozhodování o soudnictví (např́iklad v pozici ministra spravedlnosti) nebo se touto problematikou zabývaly (např́klad v ústavněprávním výboru nebo ve své politické agendě). Většina respondentů z řad soudců $(66 \%)$ pak měla zkušenost s výkonem funkce předsedy/předsedkyně soudu. U respondentů, kteří v minulosti vykonávali různé funkce jak v soudnictví, tak v advokacii, na státním zastupitelství nebo $\mathrm{v}$ politice, jsme volili jejich zařazení podle poslední aktuální funkce.

14 Srov. např. Independence and Accountability of the Judiciary. European Network of Councils for the Judiciary [online]. 2019. Dostupné z: https://pgwrk-websitemedia.s3.eu-west-1.amazonaws.com/ production/pwk-web-encj2017-p/Reports/Data\%20ENCJ\%202019\%20Survey\%20on\%20the\%20 Independence $\% 20$ of $\% 20 j u d g e s . p d f$

15 Respondenti byli vybráni záměrným výběrem na základě znalosti situace v České republice. Nikdo z oslovených respondentů žádost o rozhovor neodmítl. Celkově nám rozhovor poskytlo 9 soudců ( $\mathrm{z}$ toho 6 se zkušeností s funkcí předsedy soudu), 10 právníků ( $\mathrm{z}$ toho $2 \mathrm{z}$ nich mělo zkušeností z politiky a 1 ze soudnictvî); a 8 politiků ( $z$ nichž 2 měli bezprostřední zkušenost s prací na soudě). Namístě je i drobná stylistická poznámka: rozhovory nám poskytli jak muži, tak ženy. Pro zjednodušení nicméně dále používáme pouze sumární označení „,respondenti“, ač jsme si vědomí všech problémů spojených s používáním generického maskulina. 
Pomocí metody polostrukturovaných rozhovorů ${ }^{16}$ jsme zjišt'ovali, jak tito respondenti hodnotí současný systém správy soudnictví a jeho problémy, nakolik považují soudcovskou samosprávu za důležité téma, proč by zavedení NRS podpořili či naopak nepodpořili, a jak by podle nich mělo vypadat ideální rozdělení pravomocí mezi mocí výkonnou a mocí soudní. Rozhovory se uskutečnily od podzimu 2017 do konce roku 2019. ${ }^{17}$ V této souvislosti dodáváme, že u každé skupiny jsme se snažili o maximální diverzitu respondentů, ${ }^{18}$ nicméně jejich pohled nelze automaticky zobecnit na všechny soudce, politiky a právníky, a proto $\mathrm{v}$ dalším textu používáme označení „oslovení soudci, politici a právníci“. Pohled našich respondentů však podle nás poskytuje věrný a plastický obrázek hlavních argumentů a úvah, jež v českém prostoru k otázce NRS za poslední dvě dekády zazněly.

V samotném textu článku pak pracujeme s anonymizovanými úryvky z doslovných přepisů jednotlivých rozhovorů. Článek tím respektuje zaužívanou praxi kvalitativního výzkumu postaveného na polostrukturovaných nebo hloubkových rozhovorech, ${ }^{19}$ kdy se výpovědi respondentů upravují a editují pouze v minimální nutné míre (typicky v zájmu srozumitelnosti). ${ }^{20}$ Citované úryvky tedy zachycují autentický mluvený jazyk, který od toho psaného může být odlišný ve větné skladbě nebo stylistice. Tento autentický projev je tak mnohdy vzdálený učesanému textu novinářského rozhovoru po opakovaném redigování a autorizaci.

$\mathrm{Na}$ tomto místě musíme rovněž zdůraznit, že v článku pracujeme se širokým pojetím konceptu soudcovské samosprávy, ${ }^{21}$ který vybočuje $z$ doposud zaužívaného českého názvosloví. ${ }^{22}$ Našim cílem nicméně není samoúčelně přijít s novým pojmem,

$16 \mathrm{~K}$ této metodě srov. RUBIN, Herbert a Irene RUBIN. Qualitative Interviewing: The Art of Hearing Data. 3. vyd. Thousand Oaks, CA: SAGE Publications, 2011, 288 s.

17 Všechny rozhovory byly nahrány, přepsány a následně kódovány za pomoci software ATLAS.ti. Metodou analýzy dat byla tematická analýza, „,metoda pro identifikaci, analýzu a popis vzorců (témat) v rámci dat“ (BRAUN, Virginia a Victoria CLARKE. Using Thematic Analysis in Psychology. Qualitative Research In Psychology, 2006, roč. 3, č. 2, s. 79).

18 Hovořili jsme proto s ministry spravedlnosti z různých částí politického spektra, se soudci vyšších i nižších soudů (včetně soudních funkcionářů a představitelů Soudcovské unie) ve správní i obecné větvi soudnictví a s advokáty ve velkých i menších advokátních kancelářích. Samozřejmostí byla i geografická, věková, genderová a oborová diverzita.

19 CORDEN, Anne a Roy SAINSBURY. Using Verbatim Quotations in Reporting Qualitative Social Research: Researchers' Views. York: The University of York, 2006, s. 18.

20 Důvodem minimalizace zásahů je fakt, že př́mé citace z rozhovorů slouží v rámci výzkumu jako důkaz, ilustrace nebo vysvětlení, takže není žádoucí, aby byly měněny (jakákoliv změna totiž může posunout jejich význam). Respondenti navíc touto cestou dostávají prostor pro popsání vlastní perspektivy vlastními slovy; jakákoliv editace by tuto autenticitu nutně narušila.

21 Srov. zvláštní číslo German Law Journal o „Judicial Self-Government in Europe“ (2018, roč. 19, č. 2, s. 1567-2188).

22 Jsme si vědomi, že na takto široké definici „soudcovské samosprávy“ nepanuje v české literatuře shoda. Srov. různé pohledy českých právníků na tento koncept v KYSELA, 2008, supra n. 1. 
ale flexibilně reagovat na měnící se potřeby soudů a postihnout nové oblasti správy soudnictví, jejichž důležitost se v poslední době odhaluje společně s postupující digitalizací soudnictví či s diskusemi nad soudcovskou etikou. Pod správu soudnictví proto zahrnujeme nejen personální oblast (tedy výběr a kariérní postup soudců), oblast kárných ř́zení, rozpočtovou oblast, otázku administrativy v užším slova smyslu (zahrnující správu budov apod.), ale i vzdělávání soudců a justičních čekatelů, pravidla soudcovské etiky a oblast digitalizace soudnictvii. ${ }^{23}$ Soudcovská samospráva pak vypovídá o tom, do jaké míry se na správě těchto oblastí podílejí samotní soudci. ${ }^{24}$

Článek má následující strukturu. Nejprve v části 1 představuje klíčové debaty o NRS a shrnuje návrhy stěžejních reforem soudnictví v novodobé české historii. V části 2 prezentuje názory našich respondentů z řad soudců, politiků a právníků na klíčové problémy, kterým podle nich české soudnictví aktuálně čelí, a zda mezi ně náleží i soudcovská samospráva, resp. neexistence NRS. Část 3 je jádrem celého článku. V návaznosti na předchozí zjištění nejdříve analyzuje, jaké výhody a nevýhody má podle našich respondentů současný model správy soudnictví, přičemž ukazuje, že podle elit tkví největší problém $\mathrm{v}$ nastavení pravomocí předsedů soudů a $\mathrm{v}$ pasivitě ministerstva spravedlnosti. Dále tato část odpovídá na hlavní výzkumnou otázku, zda a proč zástupci elit podporují nebo odmítají NRS, a analyzuje jejich představy o složení a kompetencích NRS. V závěru pak článek nabízí srovnání postojů k NRS napříć jednotlivými skupinami respondentů. Soudci, politici i právníci shodně volali po větším otevření justice vůči jiným právnickým profesím, kritizovali př́liš silné postavení předsedů soudů a hrozby pro vnitřní nezávislost soudců. Lišili se nicméně $\mathrm{v}$ úvahách o tom, zda zř́zení NRS tyto problémy vyřeší. Většina soudců vznik NRS podporovala a očekává od ní sjednocení stávajícího fragmentovaného systému. Část politikủ by souhlasila s ustanovením slabého modelu NRS, pokud by kontury systému pořád nastavovalo ministerstvo spravedlnosti. Zároveň však tvrdili, že fragmentovaná správa je lepší zárukou proti ovládnutí soudnictví jednou skupinou. Právníci pak viděli v zž́zení NRS více rizik než pozitiv a obávali se zapouzdření soudní moci. Za klíč $\mathrm{k}$ řešení problémů považovali spíše otázku právnického vzdělávání a zvýšení kvality soudního rozhodování. Zdůrazňujeme, že stávající úvahy o podobně NRS, a dokonce ani aktuální novely zákona o soudech a soudcích na klíčové problémy identifikované respondenty prozatím nereagují. Náš text proto pobízí $\mathrm{k}$ otázce, zda by se debata o reformě soudcovské samosprávy neměla posunout od otázky NRS ano či ne právě k hledání řešení, jak identifikované nedostatky odstranit.

23 KOSAŘ, David. Beyond Judicial Councils: Forms, Rationales and Impact of Judicial Self-Governance in Europe. German Law Journal, 2018, roč. 19, č. 2, s. 1567-1612.

24 Srov. KYSELA, 2008, supra n. 1. 


\section{Shrnutí stavu poznání o nejvyšších radách soudnictví}

$\mathrm{Na}$ rozdíl od mezinárodních dokumentů, ${ }^{25}$ které automaticky počítají s jediným modelem NRS (soudcovská většina a rozhodující vliv NRS na jmenování a kariéru soudců), soudní (samo)správy existující např́íc Evropou jsou daleko rozmanitější co do formy i sledovaných cílů. ${ }^{26}$

Nejenže samotné NRS mají různé složení a kompetence (od tzv. „silného modelu“ v Itálii a Slovensku po „slabý model““ v Nizozemsku), ${ }^{27}$ ale řada evropských zemí místo NRS ustavila jiná soudní tělesa, která se věnují pouze vybranému segmentu kompetencí spadajících do soudcovské samosprávy. Typickým př́kladem jsou např́klad tzv. court service v Irsku a Dánsku. ${ }^{28}$ Dokonce i ministerský model v Německu a Rakousku obsahuje alespoň dílčí prvky soudcovské samosprávy, jako např́klad presidia (Präsidien) v Německu. ${ }^{29}$ Jinými slovy, model silné NRS doporučovaný evropskými institucemi se $\mathrm{v}$ důsledku moderované transformace a tlaku evropských institucí v průběhu př́stupového procesu uchytil spíše v zemích střední a východní Evropy, a i tam ne ve zcela jednotné podobě.

Co se týče cílů sledovaných zřizováním NRS, mezinárodní dokumenty obvykle pojí jejich vznik s principem soudcovské nezávislosti a dosažením lepší rovnováhy mezi nezávislostí a odpovědností soudư. ${ }^{30}$ Ustanovování NRS napříc Evropou zase obvykle deklarovalo tři základní cíle: ${ }^{31} 1$ ) nezávislost ${ }^{32}$ a odstínění politizace soudnictví, ${ }^{33}$ 2) odpovědnost soudní moci ${ }^{34}$ a 3) efektivitu soudního rozhodování. ${ }^{35}$ Podpůrně pak řada států

25 Srov. např. doporučení č. 10(2007) CCJE (Consultative Council of European Judges, což je poradní orgán Rady Evropy), z 8. plenárního zasedání konaného ve Štrasburku ve dnech 21.-23. listopadu 2007; nebo zpráva Benátské komise z 82. plenárního zasedání (12.-13. března 2010).

26 BOBEK, Michal. Pět poznámek k debatě o Nejvyšší radě soudnictví. Právní roz̧bledy, 2015, roč. 23, č. 17, s. $598-600$.

27 KOSAŘ, 2018, supra n. 23.

28 The Judicial Appointments Advisory Board in Ireland (srov. O’BRIEN, Patrick. Never let a Crisis go to Waste: Politics, Personality, and Judicial Self-Government in Ireland. German Law Journal, 2018, roč. 19 , č. 7 , s. 1871-1900).

29 Srov. WITTRECK, Fabian. German Judicial Self-Government - Institutions and Constraints. German Law Journal, 2018, roč. 19, č. 7, s. 1931-1950.

30 KOSAŘ, David. Perils of Judicial Self-Government in Transitional Societies. New York, NY: Cambridge University Press, 2016, 488.

31 Srov. URBÁNIKOVÁ, Marína a Katarína ŠIPULOVÁ. Failed Expectations: Does the Establishment of Judicial Councils Enhance Confidence in Courts? German Law Journal, 2018, roč. 19, č. 7, s. 2105-2136.

32 Zřízení NRS v Nizozemí a subsidiární reformy NRS v Itálii, Irsku, Mad’arsku a Polsku.

33 Itálie a Francie, GINSBURG, GAROUPA, 2008, supra n. 3.

34 Nizozemí, srov. také GINSBURG, GAROUPA, 2008, supra n. 3.

35 Nizozemí a Belgie, potřeba zvýšit efektivitu se pak objevuje také v návrzích reforem NRS ve Francii, Irsku nebo Polsku. 
očekávala, že zvýšení těchto hodnot povede také ke zvýšení důvěry veřejnosti v soudnictví, a tím i zvýšení jeho legitimity. ${ }^{36}$

Akademická reflexe fungování NRS je výrazně opatrnější. Pokud jde o dosažení nezávislosti, v ukazovatelích si lépe vedou zejména ty země, které mají slabé modely NRS nebo které NRS vůbec nezavedly. ${ }^{37}$ Empirické výzkumy naznačují, že existence NRS nevede k vyšší nezávislosti soudcư, ${ }^{38}$ ani nedokáže úplně odstranit přímý či nepřímý politický vliv na soudnictví. ${ }^{39}$ Tzv. euromodel NRS ${ }^{40}$ navíc ignoruje i otázku vnitřního vlivu předsedů soudů a soudních funkcionářů ve směru $\mathrm{k}$ řadovým soudcům, ${ }^{41}$ a to zejména v zemích s hierarchickou strukturou kariérního soudnictví. ${ }^{42}$ Naopak, zmínky o neblahém vlivu NRS na vnitřní autonomii řadových soudců se již dokonce objevily i ve studiích Evropské sítě Nejvyšších rad soudnictví (European Network of Councils for the Judiciary) $)^{43}$ a nejnovější literatuře. ${ }^{44}$

Př́klady ze Slovenska, ${ }^{45}$ Polska, Mad'arska ${ }^{46}$ či Rumunska ${ }^{47}$ upozorňují na další rizika spojená s NRS. Nejen, že NRS nejsou neprolomitelnou zárukou systémové nezávislosti

36 URBÁNIKOVÁ, ŠIPULOVÁ, 2018, supra n. 31.

37 Ginsburg a Garoupa např́klad zjistili, že mezi existenci silné NRS a skórem de facto soudní nezávislosti neexistuje vztah (GINSBURG, GAROUPA, 2008, supra n. 3, s. 35); BOBEK, KOSAŘ, 2014, supra n. 9; SEIBERT-FOHR, Anja (ed.). Judicial Independence in Transition. Berlin: Springer, 2012, 1378 s.

38 HALEY, Jo. Judicial Reform: Conflicting Aims and Imperfect Models. Washington University Global Studies Law Review, 2006, roč. 5, č. 1, s. 81-97; BOBEK, KOSAř, 2014, supra n. 9.

39 GINSBURG, GAROUPA, 2008, supra n. 3, s. 19. Ginsburg a Garoupa dokonce pozorovali, že v období mezi 1996 a 2005 státy, které ustanovily NRS, zaznamenaly úpadek v skóre indikátorů právního státu; Srov. i AUTHERMAN, ELENA, 2004, supra n. 5.

$40 \mathrm{~K}$ tomu srov. BOBEK, KOSAŘ, 2014, supra n. 9.

41 KOSA Ř, 2016, supra n. 30.

42 POPOVA, 2020, supra n. 9.

43 ORTIZ, Pablo José Castillo. Councils of the Judiciary and Judges' Perceptions of Respect to Their Independence in Europe. Hague Journal on the Rule of Law, 2017, roč. 9, s. 315-336.

44 Srov. SILLEN, Joost. The concept of 'internal judicial independence' in the case law of the European Court of Human Rights. European Constitutional Law Review, 2019, roč. 15, č. 1, s. 104-133; a KOSAř, David. Politics of Judicial Independence and Judicial Accountability in Czechia: Bargaining in the Shadow of the Law between Court Presidents and the Ministry of Justice. European Constitutional Law Review, 2016, roč. 13, č. 1, s. 96-123.

45 SPÁČ, Samuel, Katarína ŠIPULOVÁ a Marína URBÁNIKOVÁ. Capturing the Judiciary from Inside: The Story of Judicial Self-Governance in Slovakia. German Law Journal, 2018, roč. 19, č. 7, s. 1741-1768; a BOBEK, KOSAŘ, 2014, supra n. 9, s. 1283-1290.

46 POKOL, Béla. Judicial Power and Democratization in Eastern Europe, in Proceedings of the Conference Europeanisations and Democratisation: the Southern European Experience and the Perspective for the New Member States of the Enlarged Europe. Florencie: European Press Academic Publishing, 2005, s. 165.

47 PARAU, Christina. The Drive for Judicial Supremacy. In: SEIBERT-FOHR, Anja (ed.). Judicial Independence in Transition. Berlin: Springer, 2012, s. 619-666; anebo COMAN, Ramona a Cristina DALLARA. Judicial Independence in Romania. In: SEIBERT-FOHR, Anja (ed.). Judicial Independence in Transition. Berlin: Springer, 2012, s. 835-884. 
soudnictví, ale v řadě států navíc vedly i ke „skleníkovému efektu“ - zapouzdření soudní moci, ${ }^{48}$ vytváření klientelistických sítí a vzniku systémů vnitřní závislosti raadových soudců na soudních funkcionářích. Zvýšení nezávislosti soudů je občas také vykoupeno další judicializací veřejné politiky. ${ }^{49}$

V České republice se úvahy o NRS prvně objevily ve druhé polovině 90 . let, a to zejména v souvislosti se snahou reformovat postkomunistické soudnictví a zefektivnit výkon spravedlnosti. ${ }^{50}$ Komunistická minulost a role, jakou soudy sehrály v udržování komunistického režimu, ${ }^{51}$ přispěla $\mathrm{k}$ vưli dosáhnout důsledného oddělení soudnictví od moci výkonné. ${ }^{52}$ I v akademickém prostředí se o emancipaci soudnictví mluvilo jako o výrazu rovnováhy státních mocí a nezávislosti soudnictví, které dokáže lépe garantovat základní práva jednotlivců. ${ }^{53} \mathrm{~V}$ duchu návratu do západního demokratického světa se referenčními body staly také různé mezinárodní dokumenty, ${ }^{54}$ které předpokládaly svěření rozhodování o výběru a kariéře soudců do rukou orgánu nezávislého na výkonné moci. Tyto prameny v 90. letech silně ovlivnily i část soudců na půdě Soudcovské unie, která si od zř́izení NRS slibovala jak posílení nezávislosti v systémové rovině, tak zlepšení kvality soudního rozhodování. ${ }^{55}$

První a de facto dosud jediný vážný pokus o ustavení NRS ministra spravedlnosti Otakara Motejla stavěl právě na výše zmíněných post-tranzitních idejích. ${ }^{56}$ Motejl v roce 1999 předložil návrh na zřízení NRS jako součást širšího balíku justičních reforem, ${ }^{57}$ který se skládal z novely Ústavy a dvou zákonů, zákona o soudech a soudcích a zákona o kárné

48 Tzv. zapouzdření, tedy uzavření a izolace instituce, je jedním z rizik, které literatura pojí se vznikem silných NRS, v nichž převažuje složení z řad soudců. Srov. např. BOBEK, Michal. Pět poznámek k debatě o Nejvyšší radě soudnictví. In: Nejvyšsí rada soudnictví: Quo vadis? Sborník z konference 13.-14. kvétna 2015. Brno: Nejvyšší soud, 2015, s. 94.

49 BURBANK, Stephen. Judicial Indpendence, Judicial Accountability and Interbranch Relations. Faculty Scholarship at Penn Law, 2007, č. 98. Dostupné z: https://scholarship.law.upenn.edu/ faculty_scholarship/98/

50 Srov. BAXA, Josef. Odkud, kam, kudy a jak dál česká justice? Právní roð̧bledy, 1999, č. 5, s. 1. Obdobné závěry vyplynuly také z rozhovorů.

51 KOSAŘ, 2016, supra n. 30.

52 PIPKOVÁ, Hana a Michal MAZANEC. Soudcovská imunita a kárná odpovědnost soudců. Právní rozbledy, 1999, č. 5, s. 278-283; Srov. však i odlišný postoj proti NRS jako orgánu soudcovské samosprávy, třeba v GERLOCH, Aleš. Nad připravovanými změnami Ústavy. Právní roz̧hledy, 1999, č. 8, s. 9-17.

53 Supra n. 51, 53; nebo MOKRÝ, Antonín. Státoprávní a ústavněprávní aspekty postavení soudní moci v České republice a přpravovaná reforma soudnictví. Právní roz̧bledy, 2000, č. 2, s. 45-49.

54 Zejména Valné shromáždění OSN, 29. listopadu 1985, Základní principy nezávislosti soudnictví nebo Doporučení Rady Evropy č. R(94) 12 o nezávislosti, efektivnosti a roli soudů ze dne 13. ř́jna 1994 (Recommendation No. R (94) 12 of the Committee of Ministers on the independence, efficiency and role of judges).

55 VÁVRA, Libor. Soudcovská samospráva. Soudni roz̧hledy, 1999, č. 7, s. 213-217.

56 Srov. Ministerstvo spravedlnosti. Zásady reformy soudnictví. Právní roz̧hledy, 1999, č. 5, s. 2.

57 Návrh koncepce reformy soudnictví, rozhodnutí č. 686 ze dne 7. července 1999. Osnova návrhu byla publikována také v časopisu Právní roz̧hledy, 1999, roč. 5, č. 1, s. 1-8. 
odpovědnosti soudců. Motejl chtěl po vzoru doporučení evropských institucí nahradit stávající model státní správy soudů nejvyšší radou soudnictví, jež by centralizovala doposud roztříštěné pravomoci soudcovské samosprávy a přebrala řadu kompetencí od ministerstva spravedlnosti i od soudních funkcionářu. Návrh počítal s paritním orgánem, v němž by zasedalo 8 soudců a 8 zástupců jiných právních profesí volených na 5 let. NRS měla mít pravomoci zejména v oblasti výběru a jmenování nových soudců, ustanovování a odvolávání soudních funkcionářů a vzdělávání soudců. Motejlova ústavní reforma však nakonec v květnu 2000 nenašla v Poslanecké sněmovně potřebnou podporu. ${ }^{58}$ Sám Motejl později za důvod neúspěchu své reformy uváděl nejen absenci politické podpory, ale i „,soudní oligarchii“", do níž řadil zejména soudní funkcionáře, která se podle něj obávala zpochybnění svého mocenského postavení. ${ }^{59}$

Debata o vytvoření NRS však zcela neustrnula. V roce 2002 do ní vstoupil Ústavní soud v nálezu, v němž přezkoumával ústavnost částí nového zákona č. 6/2002 Sb., o soudech a soudcích, které se týkaly periodického hodnocení odborné způsobilosti soudců orgánem moci výkonné. ${ }^{60} \mathrm{~V}$ závěru zrušujícího nálezu se Ústavní soud výslovně vyjádřil pro posílení samosprávného elementu v českém soudnictví s tím, že „současný stav, kdy ústrednim orgánem státni správy soudu je ministerstvo spravedlnosti a soudni moc sama nemá vlastní reprezentativni orgán na jeho úrovni (kterýžto orgán by mobl být orgánem povolaným prevzít úlohu ministerstva ve vècech personálnich věetnè dobledu nad odbornou úrovni soudcovského sboru, prípadnè i v dalšich oblastech rízeni a výkonu správy soudnictví) [...] dostatečně nevylučuje prípadné možnosti neprímébo ovlivñováni soudni moci moci výkonnou (napr. prostřednictvím pridělováni rozpočtových prostredku a kontrolou jejich využivání)." ${ }^{\text {"K1 }}$ Kritiku stávající situace Ústavní soud rozvinul ještě dále v roce 2006 vlastní analýzou možných modelů správy soudnictví. Mezi řádky nálezu Pl. ÚS 18/06 týkajícího se odvolání tehdejší předsedkyně Nejvyššího soudu Ivy Brožové se dalo vyčíst, že Ústavní soud považoval za nezbytné stávající ministerský systém změnit. ${ }^{2}$ Tento závěr pak ovlivnil některé špičky justice a v debatách o soudcovské samosprávě posílil motiv zvýšení nezávislosti justice. ${ }^{63}$

58 Za návrh hlasovali ve druhém čtení pouze poslanci ČSSD.

59 MOTEJL, Otakar. Pohled ministrů spravedlnosti. In: KYSELA, Jan (ed.). Hledáni optimálního modelu správy soudnictvi pro Ceskou republiku. Praha: kancelár Senátu 2008, s. 14.

60 Nález Ústavního soudu ze dne 18. června 2002, sp. zn. Pl. ÚS 7/02.

61 Ibid.

62 Srov. nález Ústavního soudu ze dne 11. července 2006, sp. zn. Pl. ÚS 18/06.

63 Například bývalá předsedkyně Nejvyššího soudu Iva Brožová se původně prrikláněla k ustanovení NRS právě z důvodu, že takový závazek plyne ze závěru Ústavního soudu. Srov. Justiční špičky: Iva Brožová. Epravo.cz [online]. 3. 6. 2013 [cit. 15.1.2021]. Dostupné z: https://www.epravo.cz/top/aktualne/justicni-spicky-iva-brozova-91600.html; nebo HVÍŽĎALA, Karel. Vlčice: Roz̧hovory s Magdou Vašáryovou a Ivou Brožovou. Praha: Mladá fronta, 2017, 288 s.; Také několik respondentů v průběhu našich rozhovorů identifikovalo nález Ústavního soudu jako jeden z důvodů, proč přetrvávají ideje o NRS a proč je nutné se o nich bavit. Nezávislost justice byla $\mathrm{v}$ této době skloňována i $\mathrm{v}$ akademické literatuře, srov. třeba KOLBA, Jan. Nezávislost soudní moci - fikce, nebo realita? Právní roz̧bledy, 2007, č. 23, s. 860. 
Podpora soudcovské samosprávy však u ministrů spravedlnosti oscilovala mezi oběma póly. S doposud posledním legislativním návrhem na vznik samosprávného tělesa přišel ministr spravedlnosti Jiří Pospíšil v roce 2012. Návrh počítal s vytvořením smíšených komisí pro výběr soudců. Komise se měly skládat ze zástupců ministerstva spravedlnosti a soudní moci, a vybírat měly jak soudce, tak předsedy soudů. Pospíšil byl však odvolán dřiv, než návrh stihl předložit parlamentu, a jeho nástupci v tak radikální změně nepokračovali. Koaliční smlouva mezi ČSSD, ANO 2011 a KDU-ČSL z roku 2014 deklarovala zrrízení samosprávného tělesa pro správu soudnictví jako jednu ze svých priorit, avšak bez navazujících kroků. Po jistém útlumu pak debatu znovu oživila ministryně spravedlnosti Válková v roce 2015. Její mandát však opět skončil dřív, než stihla svůj pohled přetavit v jakýkoliv legislativní počin. Řada dalších ministrů, zejména Robert Pelikán, naopak Nejvyšší radu soudnictví rezolutně odmítala a k posílení soudcovské samosprávy obecně se stavěla rovněž vlažně.

Vyjma legislativních návrhů však diskuse o vytvoření NRS pokračovaly na jiných fórech a absenci dostatečné politické vůle začali zčásti kompenzovat samotní soudci. Obzvlášt' aktivní roli $\mathrm{v}$ tomto ohledu sehrála Soudcovské unie a různá neformální seskupení vrcholných představitelů justice jako např́klad tzv. ,justiční šestka“64 či trio předsedů českých vrcholných soudů. Živá debata probíhala také v akademických kruzích. Motejlova snaha o emancipaci soudnictví byla $\mathrm{v}$ tuzemských právních časopisech prezentována jako výraz rovnováhy státních mocí a nezávislosti soudnictví, které pak dokáže lépe garantovat základní práva jednotlivců. ${ }^{65}$ Po vstupu do Evropské unie se začaly častěji objevovat odkazy na mezinárodní standardy. ${ }^{66}$ Obnovil se diskurz o tom, co soudcovská samospráva znamená ${ }^{67}$ a proč je nutné český systém reformovat. Jako argument zaznívala především nezávislost soudců a odstínění výběru soudců a soudních funkcionářu od výkonné moci. ${ }^{68}$ Ćást autorů poukazovala na zastaralost státní správy soudů, která má kořeny v rakousko-uherské vizi osvíceného panovníka a v současnosti již odporuje standardům běžným v zemích Evropské unie. ${ }^{69}$ Nejčastěji zmiňovaným zdrojem inspirace byla nizozemská reforma justice. ${ }^{70}$ Až na výjimky se akademické př́íspěvky stavěly

64 Justiční šestka je neformální instituce tvořená předsedy obou nejvyšších obecných soudů, Nejvyšším státním zástupcem, zástupcem předsedů krajských soudů, zástupcem Soudcovské unie a zástupcem Unie státních zástupců.

65 Supra n. 51, 53; nebo MOKRÝ, 2000, supra n. 53, s. 45.

66 Srov. MALENOVSKÝ, Jiří. Nakousnuté sousto nezávislosti soudní moci na moci výkonné zůstává na stole. Práuni roz̧hledy, 2008, č. 8, s. 271-277.

67 KYSELA, 2008, supra n. 1.

68 Ibid.; Srov. i LICHOVNÍK, Tomáš. Nová úprava správy soudnictví. Ad Notam, 2010, č. 1, s. 14; KUČEROVÁ, Pavla. Nezávislost a odpovědnost soudců. Právní rozhledy, 2011, č. 10, s. 356-365; KOPA, Martin. Cesty (samo)správy soudů v České republice. Casopis pro právní védu a praxi, 2011, č. 1, s. 40-49.

69 LICHOVNÍK, 2010, supra n. 68.

70 SVÁČEK, Jan. Proč je nizozemská justice efektivnější než česká? Právní roẓbledy, 2004, č. 15, s. 588-594. 
za emancipaci soudnictví, at' již v podobě NRS, nebo posílení podílu soudců na správě soudnictví. ${ }^{71}$

Volání po NRS zaznělo na řadě konferencí, v nichž se angažovaly zejména oba nejvyšší obecné soudy, Soudcovská unie a justiční šestka. K poslednímu velkému střetu mezi zástupci soudnictví a exekutivy došlo v letech 2015 až 2016. V květnu 2015 Nejvyšší soud zorganizoval mezinárodní konferenci k dalšímu osudu soudcovské samosprávy v České republice, která si kladla za cíl reagovat na „diskontinuitu priorit Ministerstva spravedlnosti“672 s výše uvedenou koaliční smlouvou ČSSD, ANO 2011 a KDU-ČSL. Konference, která vyústila ve sborník, ${ }^{73}$ nabídla empirické zkušenosti s různými modely soudcovské samosprávy v Evropě, nicméně také nabídla názorovou konfrontaci mezi tehdejšími klíčovými zástupci justice, ${ }^{74}$ ministrem spravedlnosti ${ }^{75}$ a akademiky. Kromě nesouhlasu mezi zástupci justice, kteři se vyjádřili ve prospěch $\mathrm{NRS},{ }^{76}$ a ministrem, zazněly v průběhu konference i kritické hlasy, které poukazovaly na rizika spojená s NRS jako zapouzdření (tj. izolace a uzavřenî), ${ }^{77}$ nebo nejasnost co přesně by zrrízení NRS českému systému prrineslo, jaká by tato NRS měla být, a nakolik by dokázala reagovat na kritiku soudců vůči Ministerstvu spravedlnosti. ${ }^{78}$

Výměna názorů mezi justicí a ministerstvem pokračovala i v dalších letech a vyvrcholila v roce 2016, kdy Nejvyšší soud v reakci na připravovanou reformu justice ministra Roberta Pelikána (tzv. Bílá kniha), která nereflektovala soudcovskou samosprávu a nepočítala s vytvořením NRS, vydal vlastní Zelenou knihu justice. ${ }^{79}$

71 Př́kladem lze zmínit zapojení řadových soudců do tvorby rozvrhů práce. Srov. KOSAŘ, David. Rozvrh práce: klíčový nástroj pro boj s korupcí soudců a nezbytný předpoklad nezávislosti řadových soudců. Právnike, 2014, roč. 153, č. 12, s. 1049-1076.

72 Nejvyšsí rada soudnictvi: Quo vadis? Sbornike z konference 13.-14. května 2015. Brno: Nejvyšší soud, 2015 , s. 14.

73 Ibid.

74 Mezi tyto představitele patří zejména předseda Nejvyššího soudu Pavel Šámal, předseda Nejvyššího správního soudu Josef Baxa, předseda Ústavního soudu Pavel Rychetský a prezidentka Soudcovské unie Daniela Zemanová.

75 Ministr spravedlnosti Robert Pelikán.

76 Důvody preference NRS se přitom mezi zástupci justice lišily od argumentů pragmatických (problémy ministerstva v současném modelu správy soudnictví), přes potřebu posílení institucionální nezávislosti a odpovědnosti soudní moci, až po odkaz na nutnost naplnění ústavního principu dělby moci a ochrany základních práv a svobod soudy. Supra n. 72.

77 A to zejména u silných NRS, u nichž se koncentrují rozhodovací pravomoci v rukou soudců, srov. BOBEK, Michal. Pět poznámek k debatě o Nejvyšší radě soudnictví. In: Nejvyšši rada soudnictví: Quo vadis? Sborník z konference 13.-14. května 2015. Brno: Nejvyšší soud, 2015, s. 93-104.

78 KYSELA, Jan. Jinak, anebo jinak a lépe? Malá reflexe velkého tématu. In: Nejuyšši rada soudnictví: Quo vadis? Sbornik z konference 13.-14. května 2015. Brno: Nejvyšší soud, 2015, s. 126-133.

79 „Zelená kniha“ justice. Nejvyšši soud [online]. 2016. Dostupné z http://www.nsoud.cz/Judikatura/ns_ web.nsf/Zelen $\%$ C3\%A1\%20kniha $\% 20$ justice.pdf 
$\mathrm{Na}$ druhou stranu, až na výjimky ${ }^{80}$ se úvahy o organizaci soudní samosprávy zužovaly na otázku, zda NRS ustanovit, nebo nikoliv. Z debaty se postupně vytratila jasnější artikulace důvodů, proč by měla být NRS vytvořena a jak bude reflektovat a napravovat nedostatky stávajícího systému. ${ }^{81}$ Opomíjela se rovněž otázka, jaké chyby současný systém vykazuje, co by mohla konkrétně NRS vyřešit a zlepšit a co sama o sobě změnit nemůže. Místo toho se debaty koncentrovaly na technické otázky nastavení NRS, zda bude ukotvena v ústavě, jaké má mít složení a jaké kompetence jí budou svěřeny. V odborném diskurzu navíc zcela absentuje otázka, jakou povahu by NRS měla mít - zda má jít o orgán reprezentující zájmy soudní moci, nebo o těleso zapojené do správy soudnictví, které bude fungovat na principu brzd a protiváh a vyvažovat zájmy a vliv zástupců nejen širší právnické obce, ale také všech složek státní moci. Přitom právě tyto otázky jsou klíčové pro nastavení NRS, a to nejen z hlediska jejich kompetencí, ale také z hlediska otázky legitimity a výběru členů NRS a očekávání, koho budou tito členové na půdě NRS reprezentovat.

V tomto článku navazujeme na výzvu Michala Bobka, aby se debata o NRS lépe strukturovala. ${ }^{82}$ Prvním nezbytným krokem pro naplnění této výzvy je podle nás analýza názorů zástupců českých právních a politických elit na NRS. Proto si v textu pokládáme tři klíčové otázky: (1) jaké jsou důvody, které vedou oslovené elity k prosazování nebo odmítání NRS, (2) jaká očekávání případně pojí s jejím vznikem, a (3) jak si představují ideální model soudcovské (samo)správy?

\section{Vnímají elity otázku soudcovské samosprávy jako důležitý problém současného českého soudnictví?}

Téma soudcovské samosprávy a případné zřízení NRS nepatři dle právnických a politických elit ke stěžejním problémům české justice. Když jsme se respondentů ptali na tři největší současné výzvy české justice, výrazně převládala otázka kvality soudců a způsobu jejich výběru, ${ }^{83}$ následovaná výtkou vůči jejich př́lišnému formalismu a důrazu na procedurální stránku sporu, a dále pak zastaralost procesních předpisů. Forma správy soudnictví, včetně otázky soudcovské samosprávy a neexistence NRS, následovala až s odstupem za výše zmíněnými třemi výzvami. To znamená, že právnické i politické elity mají jasnou a navíc velmi podobnou představu, jaké problémy soudnictví je třeba řešit, ale již podstatně méně se zabývají tím, kdo by to měl mít na starosti a jaké by při tom mělo být zapojení samotných soudců.

80 Př́kladem lze zmínit zapojení řadových soudců do tvorby rozvrhů práce. Srov. KOSAŘ, 2014, supra n. 71; nebo ŠÁMAL, DEÁKOVÁ, 2017, supra n. 10.

81 Kritika stávající akademické reflexe se objevila např. v BOBEK, 2015, supra n. 26.

82 BOBEK, 2015, supra n. 26.

83 Způsob výběru soudců může být i otázkou soudcovské samosprávy, ale respondenti takto problém výběru soudců nerámovali a zastávali názor, že problematická jsou kritéria výběru, a až sekundárně to, kdo je vybírá. 
Kvalitu soudcovského stavu, která byla v rozhovorech obecně identifikována jako největší problém české justice, tematizovali častěji právníci než soudci nebo politici. Zpravidla přitom nešlo ani tak o kritiku špatné úrovně současných soudců (i když i ta se opakovaně vyskytla), ale spíše o obecnější úvahy o tom, jak zabezpečit, aby se do soudnictví dařilo vybírat inteligentní a kompetentní zájemce s dostatečnou morální integritou a s určitými životními zkušenostmi. S tím souvisely i přidružené otázky kárných řízení a způsobů, jak systematicky poskytovat zpětnou vazbu soudcům a řešit jejich prrípadné prohřešky a selhání. Jeden z oslovených právníků popsal klíčový význam personální stránky soudnictví a svá očekávání od soudců následovně:

Nejvètši problém té justice vždycky je a asi bude personální. Prostě aby byla obsazena lidmi, keterí jsou dostatečnè schopní, maji osobnostni integritu, jsou nèjak normálni a v̌̌dycky bude nejvíc záležet na téch lidech. To se bude promitat do visech otázek. ${ }^{84}$

S kvalitou soudcovského stavu souvisí i druhý nejčastěji identifikovaný problém, kterým je nastavení výběrových rrízení na funkci soudce. Ten ve zhruba stejné míře otevírali soudci, právníci i politici. Upozorňovali, že soudnictví by mělo být otevřeným systémem přitahujícím ty nejlepší právníky a právničky z různých oblastí života (akademie, advokacie atd.) a že v současnosti je zpo̊sob výběru nejasný, roztř́šš̌ný a bez jednotných kritérií a podmínek, což může část kvalitních uchazečů odrazovat. Objevovala se i výtka vůči prŕlišné zapouzdřenosti systému a silné preferenci justičních čekatelů před uchazeči z jiných právnických profesí a rovněž výtka vůči malým životním zkušenostem některých soudců a soudkyň (opět zejména ze strany právníků).

Následující často zmiňovaný problém, prŕlišný formalismus při rozhodování, také částečně souvisí s kvalitou soudcovského stavu. Tento problém zdůrazňovali zejména soudci a právníci, v menší míře pak politici. Upozorňovali, že část soudců se vyhýbá rozhodování skutečného jádra sporu a místo toho se soustředí zejména na jeho procesní stránku, a to proto, aby nemuseli řešit klíčové substantivní právní otázky. Jeden z respondentů tento problém pojmenoval jako ,procesualistickou posedlost“:

No a obecný neduh českébo soudnictví, ale možná, že to platí pro všechny soudn[í systémy], hlavni vlastnost soudce, vite, jaká je? [...] Pokud možno nesoudit! Hledat dưvod, proč, bud'to, že to má soudit jiný soudce, jïný soud, nemám vécnou, mistní [př́slušnost], prostě nesoudit. To je blavni vlastnost. Ale kedyž se soudi, tak katastrofa českého soudnictvi je, já to nazývám procesualistická posedlost. Prostě úplné jde stranou to materiálni právo, který je prèedmètem rízení. ${ }^{85}$

$\mathrm{S}$ tím volně souvisí i další často pojmenovávaný problém, jenž opět uváděli zejména soudci a právníci - zastaralost a př́lišná byrokratičnost procesních předpisů. Opakovaně se objevovalo volání po jejich změně, a to v oblasti civilního, trestního i správního procesu.

84 Rozhovor s právníkem L3CZ ze dne 21. března 2018.

85 Rozhovor se soudcem J3CZ ze dne 5. března 2018. 
Až na pátém místě (u soudců však společně se způsobem výběru soudců na místě prvním) se objevovala otázka správy soudnictví a absence nejvyšší rady soudnictví. Respondenti upozorňovali, že justice a soudy postrádají jasný, transparentní, kvalifikovaný a efektivní způsob řízení. Jde nejen o absenci pravidel, včetně již zmiňované úpravy výběru soudců, ale i o otázku digitalizace a automatizace nebo o promyšlenou reformu soudní soustavy (například snížení počtu okresních soudů, zavedení tříčlánkové soustavy soudů apod.). Jeden ze soudců shrnul problémy s řízením justice následovně:

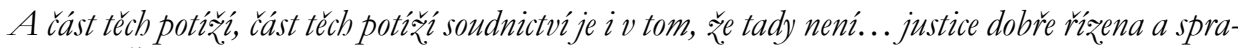
vována. Že vlastně tady není nikedo, kdo by kompetentnè, kontinuálně a prostě s jakousi pamétí, institucionální [a] bistorickou, védél, co jsou problémy justice. Nejenom, co jsou problémy, ale jaké jsou pričiny [těchto] problémů a nabidnul potom nějaká rèséní. ${ }^{86}$

Zejména soudci, a v menší míře také právníci (na rozdíl od politiků) zároveň upozorňovali, že ministerstvo spravedlnosti promyšlené a koncepční správy soudnictví není schopno, a to nejen kvůli chybějící expertize, ale i kvůli tomu, že má dost možná určitý ostych do soudnictví zasahovat, aby nebylo obviňováno z pokusů o omezování nezávislosti soudní moci. To pak dle nich vede ke stagnaci, absenci pravidel i nedostatku vize. Dalším argumentem byl také politický cyklus, který dle některých soudců neposkytuje ministrovi nebo ministryni spravedlnosti dostatek času na prrípravu a provedení potřebných reforem. I kdyby dostatek času k dispozici byl, v rozhovorech se objevil také názor, že není vhodné, aby ministr zaváděl reformy, které přesahují dobu jeho mandátu, což naznačuje silnou nechut' vưči samotnému ministerskému modelu správy soudnictví:

My máme v ČR tzv. ministerský model. To znamená, že ministerstvo spravedlnosti je tím orgánem, který má analyzovat činnost justice, má se zabývat tim, jakéjsou tam nedostatky, a jak.je prípadnè rešit. A ministerstvo spravedlnosti na tuto úlohu rezignuje [...]. Dèlá to proto, žze ministerstvo jako takové má jiné úkoly. V současné době prevažuji jiné politické úloby, které ten ministr plní. A je pro něj de facto nemožné a zpolitickébo blediska i nezodpovédné, aby se vènoval otázkám, keteré naprosto jasně présabuji dobu jeho mandátu. ${ }^{87}$

Oslovení soudci (a v menší míře i právníci) spatřují řešení právě v ustanovení NRS, která by disponovala nejen hlubokými znalostmi o fungování justice, ale zabezpečovala by i určitou kontinuitu a zároveň by garantovala, že navrhované kroky a reformy by se neděly čistě v područí moci výkonné. Právě v neexistenci nejvyšší rady soudnictví vidí oslovení soudci hlavní problém správy justice, který se pak promítá do dílčích otázek, jako je např́iklad absence jasných pravidel pro výběr soudců. Argumentují, že v současnosti na centrální úrovni neřešené personální otázky, včetně povyšování, přestupů a stáží soudců nebo kontroly práce soudních funkcionářù, by NRS mohla mít na starosti. U některých soudců se k těmto praktickým argumentům pro zřízení nejvyšší rady soudnictví prridávaly také argumenty normativní, opřené o jejich představy o nezávislosti

86 Rozhovor se soudcem J9CZ ze dne 10. července 2018.
87 Rozhovor se soudcem J5CZ ze dne 5. dubna 2018. 
soudní moci. Soudní moc dle nich nesmí být řízena mocí výkonnou, protože součást její nezávislosti považují také nezávislost administrativní. Dle jednoho ze soudců je současné nastavení, kdy soudní moc spravuje zejména ministerstvo spravedlnosti, dokonce v rozporu s ústavním pořádkem:

Tak na pronim mistě samozřjejmě budu jmenovat neexistenci nejvyššr rady soudni moci. [...] Tak.že myslim, že to je z blediska délby moci pruni problém. To znamená administrativni závislost soudnictví. Aby to nevyznèlo špatně, já jsem presvědřen o tom, že soudnictvi je nezávislé. Ale bavime se o rozhodovaci ćinnosti. Ale vedle toho máme taky termín administrativni nezávislosti. [...] A takeže do té doby, dokud bude soudni moc rízena moci výkonnou, jsem presvèdčen, že v rozporu s ústavním porádkem, take to budu vždycky označovat jako prvni a hlavni problém fungováni soudnictví $v$ Ceské republice. ${ }^{88}$

Celkově se na základě rozhovorů jeví, že na pojmenování největších problémů českého soudnictví se hlavní aktéři shodnou, ale nad širší otázkou, kdo a jak by je měl řešit, již konsenzus nepanuje. Zatímco soudci zpravidla spojují tyto problémy s kritikou nekoncepčního a nesystematického zpo̊sobu správy soudnictví ze strany ministerstva spravedlnosti, a druhým dechem obvykle dodávají, že toto dlouhodobé selhávání by nejvyšší rada soudnictví pomohla napravit, právníci a politici se soustřed’ují na věcnou stránku pojmenovávaných problémů, bez preference toho, zda by je mělo řešit ministerstvo spravedlnosti, nebo potenciální nejvyšší rada soudnictví.

Nad rámec již řečeného lze na základě rozhovorů ještě dodat, že samotná správa soudnictví nemá dle právnických a politických elit přímý vliv na důvěryhodnost justice jako takové. Nejvyšší rada soudnictví by dle některých soudců mohla pomoci tomu, aby měla justice své jasně identifikovatelné představitele a silný hlas, ale jinak převládala představa, že posílení role soudců v oblasti správy soudnictví by mělo vliv na důvěru veřejnosti pouze $\mathrm{v}$ případě, že by vedla $\mathrm{k}$ lepšímu a efektivnějšímu systému řízení než současný ministerský model.

\section{Potřebuje české soudnictví NRS?}

Přesto, že většina oslovených soudců, politiků a právníků neidentifikovala formu správy soudnictví jako klíčový problém, který musí aktuálně justice řešit, jednotlivé problematické oblasti jako je výběr a kvalita soudců nebo nedostatky na straně ministerstva spravedlnosti se správou soudnictví přímo souvisí. V následující části se proto podíváme blíže na to, jak oslovené elity hodnotí současný model správy soudnictví a zda vidí nedostatky v rozdělení moci mezi soudci a politiky. Na základě toho pak prriblížíme, jak se zástupci jednotlivých elit stavějí k zřízení nejvyšší rady soudnictví, a proč by př́padně její vznik podpořili, nebo proti němu naopak brojili.

88 Rozhovor se soudcem J6CZ ze dne 27. dubna 2018. 


\subsection{Systémové problémy ve stávajícím modelu správy soudnictví}

Oslovené elity společně identifikovaly řadu problémů a nedostatků, ale i pozitivních charakteristik, které se týkají působení dvou klíčových aktérů správy soudnictví: ministerstva spravedlnosti a předsedů soudů (Tabulka 1).

Tabulka 1: Přehled negativ a pozitiv identifikovaných zástupci elit v současném systému správy soudů

\begin{tabular}{|c|c|c|}
\hline & Ministerstvo & Předsedové soudů \\
\hline \multirow[t]{8}{*}{ Negativa } & Neschopnost řídit & Nedostatek kvalifikace \\
\hline & chybi odbornost & Zdvojení rolí a konflikt zájmů \\
\hline & chybi kontinuita & Absence kontroly a roztř́šštěnost \\
\hline & chybi vize & Snižování vnitřní nezávislosti soudců \\
\hline & chybi vile & Absence politické legitimity \\
\hline & Závislost na výsledcích voleb & Zapouzdření justice \\
\hline & Riziko snadné politizace & \\
\hline & Absence komunikace se soudci & \\
\hline \multirow[t]{2}{*}{ Pozitiva } & $\begin{array}{l}\text { Zajištění materiálních podmínek } \\
\text { fungování = odlehčení agendy soudců }\end{array}$ & \\
\hline & Přímá politická odpovědnost & \\
\hline
\end{tabular}

Zdroj: autoři

Co se týče role ministerstva spravedlnosti, respondenti identifikovali celkem čtyři nedostatky: funkční neschopnost řídit správu soudnictví, závislost na výsledcích voleb, riziko snadné politizace a absenci komunikace se soudci (Tabulka 1). Je důležité zdůraznit, že tato negativa respondenti identifikovali bez ohledu na to, zda podporovali zř́zení NRS, či nikoliv.

Nejkritičtěji se k roli ministerstva stavěli soudci, u nichž se objevily všechny čtyři typové argumenty. Z těchto čtyř argumentů pak nejčastěji upozorňovali na funkční selhávání ministerstva. Soudci ministerstvo shodně označovali za silné, ale neschopné efektivně soudy řídit, at' již z důvodu nedostatku kapacity, odbornosti, nebo z nedostatku politické vůle navrhovat a realizovat dlouhodobá koncepční řešení. Ministerstvo podle oslovených soudců postrádá expertizu, a proto se soustředí pouze na parciální problémy. „Nedèlá to [...] ze dvou dìvodi. Zaprvé, nechce být obvinèno z. toho, že zasahuje do nezávislosti justice. A zadrubé, ažt tak tomu úplnè teda nerozumi." 89

Kritika způsobu rrízení na straně ministerstva zaznívala také z řad právníků, kterým podobně jak soudcům vadilo, že ministerstvo nemá dlouhodobější vizi, chybí mu kontinuita a směřování: „Je neprǐjemné, [...] ]̌̌e ministerstvo vlastně nemá žádný systém. Z mébo pobledu,

89 Rozhovor se soudcem J8CZ. Tento závěr podpořil také jeden oslovený právník, který vztah ministerstva $\mathrm{k}$ předsedům soudů prrirovnal k tzv. hře s nulovým součtem: „někomu přidá, a někomu ubere“. 
kdy ̌̌jako to chce rešit ministerstvo a politika, tak at’ to re řsi systémově. Oni tam prece nejsou od toho, at' to rozhoduji ad hoc." $" 90$

Druhý a třetí argument, který opět zazníval zejména z řad soudců, byla vázanost činnosti ministerstva na výsledky voleb a latentní hrozba snadné politizace soudnictví. Zde tedy již soudci upozorňovali nejen na pragmatickou rovinu nevhodného způsobu, jakým ministerstvo správu vykonává, ale zpochybňovali podstatu a legitimitu přidělení kompetencí v této oblasti politickému orgánu. Podle soudců by ,soudnictvi v demokratické společnosti mělo být nezávislé na výsledku voleb".91 Zároveň soudci upozorňovali, že ministerstvo soustřed'uje ve svých rukou tolik moci, a to zejména v personální oblasti, že justice má vlastně ,velké štèstí, že tam neni ministr, keterý by chtěl těchto [pravomocí] využivat"." Zde se nicméně názory soudců rozcházely. Jiný dotázaný soudce naprríklad kontroval pozorováním, že ke zneužití pravomocí ministerstva nikdy nedošlo a naopak, model české soudcovské správy svěřil velkou moc do rukou předsedů soudů:

Ten model, kede to je soustrèè̌ný v̌̌echno v rukách ministra spravedlnosti [...] v̌sechna jmenováni v'̌ech státních zástupců, věech soudců [...] Dokonce tenkerát [v 90. letech] se skládal slib ne do rukou prezidenta, ale do rukou ministra [...] prezident jmenoval, ale slib se skládal do rukou ministra spravedlnosti. [Přresto] ve skutečnosti nedošlo k tomu, že by néjaký ministr spravedlnosti zneuřil tu pravomoc a ovlivnoval soudnictví. Ten model ve skutečnosti vytvoril obromný prostor pro prèdsedy krajských soudu. A ti vládli justici a vládnou dodneška. Protože, jakj jem ríkal, soudcouská práce se stala velmi atrak.tivni. Ty záruky nezávislosti, královský platy [...] prostè soudci získali obromný podminky. ${ }^{33}$

Čtvrtý kritický argument jsme zaznamenali naopak u politiků. Ti zčásti sdíleli praktické výtky $\mathrm{k}$ nedostatkům a selháním na straně ministerstva spravedlnosti (zejména absentující vizi kam směrovat další reformy), avšak také upozornili, že jednou z příčin neefektivního řízení je nedostatečná komunikace mezi exekutivou a soudci. Jeden z politiků upozornil, že český systém počítá s předsedy soudů coby prodlouženou rukou ministerstva, ti nicméně ministerstvo vnímají jako svého oponenta: „Préedsedové se nechápou jako prodloǔ̌ená ruka ministerstva, coそ̌ ale ideálni model predpokládá. Jsou spiše v opozici, byt’ otevreně nikedy nerevoltovali." "94

Je důležité také zdůraznit, že právníci a politici se s oslovenými soudci rozcházeli právě v systémové kritice ministerstva spravedlnosti. Podle soudců by mělo ministerstvo pouze vytvářet materiální podmínky pro rozhodování a uvolnit tak ruce přehlceným předsedům soudů - nicméně tak nedělá a kompetence na předsedy naopak deleguje. Právníci a politici sice uznávali praktické nedostatky, ale zdůrazňovali, že ze systémového hlediska

90 Rozhovor s právníkem L2CZ ze dne 21. března 2018.

91 Supra n. 88.

92 Rozhovor se soudcem J9CZ ze dne 31. května 2018.

93 Supra n. 85.

94 Rozhovor s politikem P8CZ ze dne 15. listopadu 2018. 
na vrcholu správy soudnictví musí stát politický aktér, jelikož jedině ministerstvo, nikoliv samosprávný soudní orgán, může nést přímou politickou odpovědnost:

...dnes tedy to posledni slovo má exekutiva. To že posledni slovo nevyuživá, je jedna věc, ale jaksi jsem rád, že tím nominátorem, nebo legitimizátorem, je někdo, kdo prece jenom vžešel zuvoleb. ${ }^{95}$

Konečné slovo ministerstva funguje jako systém brzd a protiváa ${ }^{96}$ proti př́liš silnému soudnictví. Podle dalšího právníka „z hlediska ideálního nastaveni společnosti by mély pravomoci vycházet od poslancü, byt’ se ukazuje, že zákonodárce neni v soǔáasné době premiantem akènich postupü“.97 Druhá velká skupina identifikovaných nedostatků systému správy soudnictví se dotýkala postavení předsedů soudů. Zástupci všech tří elit nejčastěji upozorňovali na nesoulad de facto a de jure stavu, v němž politická odpovědnost a legitimita náleží ministerstvu spravedlnosti, to ale de facto výkon správy soudnictví deleguje na předsedy soudů. Celkově se mezi respondenty objevilo šest kritických argumentů vưči silnému postavení předsedů soudů: (1) nedostatek kvalifikace $\mathrm{v}$ určitých oblastech správy soudnictví, (2) zdvojení rolí a konflikt zájmů, (3) negativní vliv na vnitřní nezávislost raadových soudců, s čímž souvisí také (4) absence nezávislé kontroly, jak kvalitně předsedové správu ve skutečnosti vykonávají. Silné a autonomní postavení předsedů vede také k (5) fragmentaci celého systému a (6) k zapouzdření soudnictví vůči vnějšími světu (Tabulka 1).

Oslovené elity se shodly na tom, že předsedové soudů mají př́liš silné postavení, které přináší zejména negativa. Za prvé soudcům vadila přetíženost předsedů soudů, a to zejména u kompetencí, ke kterým nemají potřebnou kvalifikaci. Podle soudců předsedové nejsou kvalifikováni prijímat rozpočtová rozhodnutí a nést odpovědnost za jakoukoli správu nad rámec běžného provozu soudu: „Predsedové nejsou odbornici, radě věci vůbec nemůžou rozumèt...". Stávají se proto téměř závislými na ředitelích správy, „dokonce nes[ou] za jebo práci odpovědnost “ ${ }^{98}$ I podle politiků a právníků by předsedové neměli nést odpovědnost za velká investiční a ekonomická rozhodnutí, ${ }^{99}$ jelikož nemají potřebné vzdělání ani zkušenosti. Výkon těchto kompetencí proto zbytečně vede ke kárným řízením. ${ }^{100}$

Za druhé, mezi soudci se objevil argument, že z povahy postavení předsedů soudů se ve správě soudnictví musí nutně projevovat konflikt zájmů a dochází u nich ke „zdvojení jejich rolí. ${ }^{101} \mathrm{~J}$ sou totiž souběžně v pozici subjektů i vykonavatelů správy soudnictví. Nutně proto u nich dochází ke střetu zájmů: ${ }^{102}$ „prèedsedové jsou pouẓe hráči na poli, jejich zájmy

95 Rozhovor s právníkem L6CZ ze dne 14. března 2018.

96 Rozhovor s právníkem L3CZ ze dne 21. března 2018.

97 Rozhovor s právníkem L5CZ ze dne 21. března 2018.

98 Supra n. 88.

99 Rozhovor s politikem P6CZ ze dne 23. listopadu 2018 a P4CZ ze dne 8. listopadu 2018.

100 Respondenti to demonstrovali zejména na př́kladu Jaroslava Pořízka a kárného řízení kvưli Justičnímu paláci v Brně.

101 Supra n. 87.

102 Tato argumentace se objevovala zejména u soudců, kteří prosazovali zřízení NRS. 
jsou nutnè ruizné. Chybí [jim] jednotná koncepce. " ${ }^{103}$ Předsedové budou mít podle respondentů vždy problém reprezentovat celou soudní moc a hlas soudců, kteř́ jsou vůči nim zároveň v zaměstnaneckém vztahu. Ač se to podle nich v praxi zatím často neděje, soudci si uvědomovali, že príliš silné postavení př̌edsedů soudů může vést $\mathrm{k}$ závislému postavení řadových soudců.

Třetím často kritizovaným důsledkem současné dělby pravomocí byl nedostatek koordinace mezi předsedy soudů navzájem. Každý předseda vládne autonomně (jeden ze soudců označil prèedsedy krajských a okresních soudů za "neomezৃené feudálni pány "104) a nastavuje jiná pravidla (,je evidentní, že máme krajské právo ve správě, to znamená, že jsou obrouské rozdíly mezi tím, jak postupuje jeden predseda krajského soudu a jak druby “"105), což vede k velké fragmentaci systému, tedy roztrúššěnosti a nejednotnosti způsobu, jakým je správa

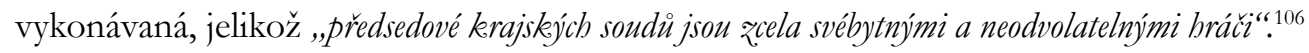
To zároveň vede ke čtvrtému negativnímu jevu, a to snižování vnitřní nezávislosti řadových soudců. Model se silnými předsedy, v jejichž rukou spočivá veškeré de facto rozhodování o personálních otázkách, navíc bez politické kontroly, vede $\mathrm{k}$ velké vnitřní závislosti řadových soudců okresních a krajských soudů na svých předsedech. Na rozdíl od soudců, kteří tvrdili, že silné postavení předsedů představuje hrozbu, ale nedochází $\mathrm{k}$ jeho zneužívání, právníci otevřeně upozorňovali na situace, $\mathrm{kdy}$, soudci maji ₹ [...] prédsedy strach ". ${ }^{107} \mathrm{U}$ právníků se tak objevovalo implicitní tvrzení, že soudci nemají dostatek záruk vnitřní nezávislosti ve vztahu k vlastním předsedům a dalším soudním funkcionářủm. Zatímco tedy podle oslovených institucionální nezávislost soudců posiluje, vnitřní nezávislost s rostoucím vlivem předsedů oslabuje. Zejména politici prítom zdůrazňovali, že kontrola výkonu pravomocí předsedů není ,zasahování politické moci do té moci soudní, ale že nad každj́m, kdo vykonává néjakou práci, musi být nèjaký dobled".108

Pátý argument, který respondenti zmínili, se dotýká teoretických principů dělby moci a vyvažování jednotlivých mocí. Předsedové soudů podle oslovených soudců na rozdíl od ministerstva postrádají politickou odpovědnost, sice disponují velkým vlivem a pravomocemi, ale jen $\mathrm{v}$ de facto rovině. Většina oslovených soudců se ale rovněž vyjádřila, že pouhé formalizování současného stavu, tedy přesun výkonu pravomocí z ministerstva spravedlnosti na předsedy soudů, také není řešením, a to jednak kvůli chybějící legitimitě, a zároveň kvưli nedostatku kvalifikace napřs. v rozpočtových otázkách a také nepřiměrenému vlivu př̀edsedů na řadové soudce.

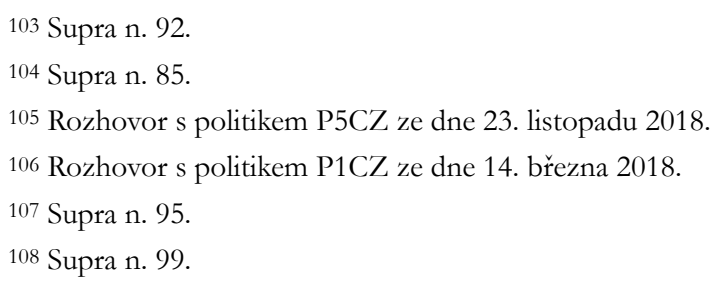


Konečně, šestou výtkou, která zaznívala např́ič třemi elitami, a panovala na ní shoda i mezi zastánci a odpůrci NRS, byla zapouzdřenost justice, k níž podle oslovených přispívají právě silní předsedové soudů. Autonomie předsedů v personálních otázkách vede podle nich $\mathrm{k}$ nedostatečné transparentnosti a formování systémů, které dovnitř justice nevpustí právní experty z jiných odvětví.

Z reflexe současného způsobu, jakým je správa soudnictví v ČR organizována, tak plyne, že se stávajícím stavem není nikdo z oslovených zcela spokojen. Kritické výtky se pohybovaly bud' v rovině funkční (jak daní aktéři správu vykonávajî), nebo systémové (zda by správu vůbec vykonávat méli). Překvapivě se soudci s politiky shodli na tom, že více než systémové problémy a neblahý dopad na nezávislost soudnictví zdůrazňovali pragmatické nedostatky na straně ministerstva spravedlnosti. Právníci také kritizovali způsob, jakým ministerstvo správu soudnictví řídí, většina z nich by však rozdělení pravomocí nepřreskupovala.

Ještě silnější konsenzus mezi oslovenými elitami panoval ohledně príliš silného postavení předsedů soudů. Soudci, kteří kritizovali př́lišnou přetíženost, roztrríštěnost a autonomii předsedů, z vzniklého stavu vinili ministerstvo spravedlnosti. Politici a právníci převážně tvrdili, že chyby, které systém vykazuje třeba v podobě zapouzdření justice, nesouvisí s dělbou kompetencí mezi soudce a politiky. Obě skupiny by kompetence spíše nepřeskupovaly. Pokládaly však za klíčové, aby systém vyvažoval zájmy a vliv moci soudní, která však nesmí být závislá na ad hoc rozhodnutích ministra, a moci výkonné. Je to dle nich totiž exekutiva, kdo má demokratickou legitimitu, a proto by měla také nastavovat kontury jednotného systému.

\subsection{Dokázala by NRS vyřešit systémové nedostatky správy soudnictví?}

S ohledem na systémové problémy, které respondenti identifikovali v současném modelu správy soudnictví, jsme se dále zaměřli na otázku, zda by NRS byla jejich řešením. Ptali jsme se proto, zda zástupci elit podporují vytvoření NRS, a pokud ano, jakou by měla mít podobu a jaká od ní mají očekávání.

Celkově se mezi oslovenými zástupci elit objevilo sedm typů argumentů (Tabulka 2), z nichž čtyři zdůrazňují pozitiva zavedení NRS: 1) jednotná koncepce správy, 2) reprezentace soudnictví, 3) odlehčení agendy předsedů soudů, potažmo jejich oslabení, 4) prevence ingerencí moci výkonné. Tři argumenty naopak upozorňují na rizika NRS, a to konkrétně 5) křehkost NRS a náchylnost k politizaci, 6) zapouzdření soudnictví a 7) nedostatek odpovědnosti soudců. Jak jsme zmínili v části 1, NRS vznikající v zahraničí obvykle jako klíčový cíl deklarovaly posílení nezávislosti soudní moci, zvýšení odpovědnosti soudců a zlepšení efektivity výkonu spravedlnosti. Je proto zajímavé, že u českých elit byla nezávislost zdůrazňována minimálně. Argument nezávislostí se vyskytl pouze nepř́mo u soudců, kteří poukazovali na latentní hrozbu, že ministerstvo spravedlnosti zneužije velkou koncentraci de jure pravomocí. NRS by podle nich mohla fungovat 
jako lepší prevence zásahů do soudcovské nezávislosti a brzda proti hrozbě ovládnutí soudní moci. Tento názor byl ve střetu s postojem politiků, jejichž část se naopak domnívala, že právě skutečnost, že současný český systém správy soudnictví je roztříštěný a figuruje v něm řada aktérů s protichůdnými zájmy, garantuje, že je relativně rezistentní a že soudní moc nelze lehce ovládnout jediným hráčem.

Tabulka 2: Výhody a rizika spojená se zř́zením NRS

\begin{tabular}{|l|l|l|}
\hline \multicolumn{2}{|l|}{ Výhody } & Rizika \\
\hline Soudci & jednotná koncepce & křehkost (politizace) \\
& reprezentace & \\
\hline & odlehčení agendy předsedů soudů & \\
\hline prevence ingerencí exekutivy & \\
\hline Politici & reprezentace & křehkost (politizace) \\
\hline & sjednocení personální politiky & zapouzdření \\
\hline & & absence legitimity \\
\hline Právníci & reprezentace & absence poptávky \\
\hline & oslabení předsedů soudů & absence poptávky \\
\hline & & zapouzdření \\
\hline & & křehkost (politizace) \\
\hline
\end{tabular}

Zdroj: autoři

V souladu s naším očekáváním měla NRS největší podporu mezi soudci. Zatímco politici i právníci vyjádřili obavy, že zřízení NRS by soudce (a zejména předsedy soudů) ještě více posílilo a dále tak prohloubilo zapouzdření justice, soudci samotní tvrdili, že nárůst pravomocí a posílení vưči ostatním složkám moci není účelem snah o NRS. V NRS spatřují soudci řešení ryze funkčních otázek: jak soudnictví řídit, jak zajistit kontinuitu a jednotnost systému, jakož i reprezentaci soudnictví vưči dalším dvěma složkám moci (Tabulka 2). Někteří oslovení soudci, kteří měli zkušenost s postavením soudních funkcionářů, také uvedli, že zřízení NRS by umožnilo odbřemenit předsedy soudů od administrativních úkolů spojených se správou soudnictví. Klíčovou rolí soudců by mělo být souzení, nikoliv vedení soudu. Přínos ve smyslu reprezentace soudní moci připouštěli také politici, nicméně u většiny z nich to nebyl dostatečný argument na to, aby se klonili ke zř́zení NRS.

Politici a část právníků se po vzoru př́kladu ze Slovenska, Mad’arska či Polska také obávali, že NRS bude př́liš křehkým a lehce ovládnutelným orgánem, jenž bude náchylný na politizaci. Někteří soudci tuto kritiku připustili, nicméně trvali na tom, že u NRS budou převažovat pozitiva, zejména pokud se dobře nastaví její složení. Pouze jeden oslovený soudce vyjádřil obavu, že NRS neodvratně povede k rozmělnění odpovědnosti. V další části podrobněji rozebereme argumenty vznesené jednotlivými skupinami respondentů. 


\subsubsection{Očekávání soudcu}

Jak jsme již uvedli, většina soudců zřízení NRS podporovala. Čtyři klíčové argumenty, kterými soudci potřebu NRS odůvodňovali, byly 1) efektivita rrízení správy soudnictví, 2) kvalita soudního rozhodování, 3) reprezentace soudnictví a 4) otázka nezávislosti, nicméně pouze $\mathrm{v}$ systémové a preventivní rovině.

Klíčový důraz na zlepšení efektivity správy soudnictví plynul právě z nespokojenosti s tím, jak správu soudnictví vykonává ministerstvo spravedlnosti. NRS by podle soudců prrinesla jasnou vizi, větší kontinuitu a institucionální zastřešení soudní moci, a odstranila by závislost justičních reforem na politickém rozhodování, které soudnictví coby jedné ze složek státní moci nepřísluší. ${ }^{109}$

Bezprostředně s efektivitou soudci pojili druhý argument, a to že zřízení NRS povede ke zvýšení kvality soudního rozhodování, protože soudcům poskytne kvalitnější a koncepční řízení, „prinese dialog a kontrolu reforem "110 či zlepší „komunikaci s médii i navenek."111 Soudci se domnívali, že NRS dokáže „odstranit současné problémy s výbèrem soudcư a soudnich funkcionárư "112 resp. zajistí lepší a více transparentní a otevřený model výběru. Jiný oslovený však naopak upozornil, že NRS není automaticky všelékem a může současné problémy vyřešit pouze v závislosti na tom, ,jak bude koncipována a kedo se tam dostane, koho tam zuoli". 113

I v rámci třetího očekávání, reprezentace, soudci zdůrazňovali, že jádrem soudcovských snah o zrrízení NRS není posílit justici, nýbrž zajistit její jednotnou reprezentaci. NRS proto „nemá mít mocenské kompetence, ale reprezentovat, o to jde ${ }^{\text {“. }}{ }^{114}$

Čtvrtý argument, dopad na nezávislost, byl zajímavý a rozděloval nejen jednotlivé skupiny respondentů, ale i samotné soudce. $\mathrm{Na}$ jednu stranu by zř́izení NRS podle části soudců ,pomohlo ustát ingerence výkonné moci do soudnictvi“. ${ }^{115}$ Jak jsme již ale zmínili, tyto argumenty byly doplněné také konstatováním, že soudci se cítili de facto nezávislí. Lze je interpretovat tedy i tak, že potenciální problémy a „prríležitosti“ ovlivňovat nezávislost soudců viděli právě v systémové rovině. $\mathrm{Na}$ druhou stranu jeden z oslovených soudců také upozornil, že NRS může naopak vést k rozmělnění odpovědnosti, jelikož soudci

\footnotetext{
109 Respondenti z řad soudců tvrdili, že je nutno odlišit řízení soudnictví (ministerstvem spravedlnosti) od jiných ministerských resortů. Byt' ta také vyžadují dlouhodobé koncepce a řešení, soudnictví se odlišuje právě tím, že představuje jednu ze složek státní moci.

110 Rozhovor se soudcem J9CZ ze dne 10. července 2018.

111 Supra n. 110.

112 Supra n. 87.

113 Supra n. 92.

114 Ibid.

115 Supra n. 87.
} 
nenesou žádnou politickou odpovědnost a v NRS by se navíc mohli ukrýt za kolektivní orgán. ${ }^{116}$

Převážná většina argumentů, jež soudci vznesli ve prospěch NRS, se tak netýkala rozdělení kompetencí mezi mocí soudní a mocí výkonnou, ale reálných schopností ministerstva zajistit efektivní správu soudnictví. ${ }^{117}$ Řada soudců např́klad uvedla, že zavedení NRS ani nemá za cíl a priori zvýšit nezávislost soudnictví: „I v Nizozemi se soudní rada nezavedla pro zlepš́eni nezávislosti, ta již byla dobrá. Spiše jako pojistke do budoucna."118

Podle dalších soudců navíc útoky na soudy v Mad'arsku, Polsku a na Slovensku ukázaly, že ani NRS není neprůstřelná pojistka nezávislosti do budoucna. Jedna z oslovených soudkyň dokonce uvedla, že rizika spojená s NRS, která se odhalují v sousedních zemích, vedla u ní ke změně názoru na NRS:

Vliv formy správy soudnictvi na kvalitu justice se preceñuje. Soudni radu bych již nepodporila, ne po ukázkách z Mad'arska, Polska a Slovenska. Neuchrání nezávislost. Naopak, vede k rozmèlnèni odpovédnosti, jelikožje tě̌žé pojmenovat, kdo je odpovédný, kedo stoji za jednotlivými kroky. Projevuje se żde nevýhoda kolektivního orgánu oproti individuálnimu. ${ }^{119}$

Pokud jde o formu, kompetence a složení NRS, soudci, kteří NRS podporovali, se shodli na pěti kritériích, která do značné míry kopírovala také doporučení mezinárodních orgánů: paritní složení, široké kompetence v personální oblasti a běžné správě, možnost hodnotit soudce, připomínkování zákonů a reprezentace soudnictví navenek.

Složení představovalo pro soudce nejdůležitější otázku. Pravděpodobně v návaznosti na to, že české soudnictví viděli jako uzavřený systém, zdůrazňovali také, že NRS nesmí být „odborárškým orgánem nebo justični pevnosti“", 120 a to i přes paritu nebo malou převahu soudců ve složení NRS:

Tak.že já jsem zase za to, aby třba predseda [NRS] byl žrad soudcü, aby to vlastnè byl opravdu ten orgán soudni moci. Ale spiš bych se prikilánéla k paritè, a pokud by to nebylo možné [kvưli riziku sudého počtu a nepřijetí rozhodnutí], tak aby o jeden nebo velmi minimálně ten počet soudců prevládal. Ale jenom proto, aby ten orgán byl akceschopny. ${ }^{121}$

116 Rozhovor se soudcem J4CZ ze dne 16. března 2018.

117 Výjimkou byli pouze politici, kde naopak argument týkající se dělby moci a z ní plynoucí politické odpovědnosti, kterou soudnictví nemůže nést, zazníval relativně často.

118 Rozhovor se soudcem J7CZ ze dne 6. dubna 2018; Srov. i MAK, Elaine. Judicial Self Government in the Netherlands: Demarcating Autonomy. German Law Journal, 2018, roč. 19, č. 7, s. 1801-1838. Ve skutečnosti zřízení nizozemské NRS sledovalo kromě zefektivnění soudnictví také cíl posílení nezávislosti soudo̊ a omezení vlivu politiků na jejich rozhodování. Srov. LANGBROEK, Philip. Organization Development of the Dutch Judiciary, between Accountability and Judicial Independence. International Journal for Court Administration, 2010, roč. 2, č. 2, s. 21.

119 Supra n. 116.

120 Ibid.

121 Ibid. 
Zásadním proto podle respondentů bude zajistit kvalitní personální obsazení NRS:

A v tuto chvíli [...] zásadni bude zajistit vlastně osobni, personálni obsazeni toho orgánu tak, aby tam skutečně byly osoby, k.teré budou chtit naplnovat ty úkoly, a ne żneuživat moc. A vždycky je nutno si ríci: „Konstitunjeme orgán, který bude mít velký vliv. Bude to prítahovat osoby, které budou mít opačné zájmy. A i uvnitř v soudnictví je jïch plno."

Jedna respondentka v souvislosti s tím uvedla, že kvalitu obsazení by mohl zajistit systém volitelů:

Já bych preferovala ten systém, protože z. mého pobledu eliminuje takovou tu populistickou a zavádèjici kampaň a préci jen tèch osob, které se zajimaji o organizaci justice a které jsou schopné definovat, ž to toto, tento návrh třeba nemưž̀ vést ke ničemu, tento je populistický a tento naopak. ne, tak tèchto osob zas tolik neni. Takže z mého pobledu sniženi toho rizika by bylo zpuisob volby voliteli. ${ }^{123}$

Nutno říci, že při otázkách na složení NRS se soudci většinou omezovali na příslušnost členů ke skupině soudců a nesoudců, nikoliv na to, kdo by měl kterou část členů vybírat a jak. Jinými slovy, zdá se, že respondenti automaticky předpokládali, že soudci sedící v NRS by reprezentovali zájmy soudnictví bez ohledu na to, kdo by je do NRS vybral. Přitom to, v jakém vztahu vystupují volení zástupci soudců, se ukázalo klíčovým faktorem na Slovensku, kde standardně do NRS jmenují soudce i orgány moci výkonné. V Soudní radě Slovenské republiky proto měli soudci vždy výraznou většinu, ačkoliv úmysl ústavodárce byl odlišný - parita. ${ }^{124}$

Co se týče kompetencí, oslovení soudci se jednomyslně shodli na tom, že klíčovým úkolem NRS by měla být personální politika, tj. výběr soudců a jejich profesní postup. Tento argument souvisí hned se dvěma negativy, které soudci ve stávajícím systému identifikovali: nízkou kvalitou soudců a uzavřeností systému, který je navíc nejednotný a netransparentní, a tím zakládá prostor ke zneužití a „ovlivňováni soudnictvi“. ${ }^{125}$

Většina soudců se také shodla na tom, že přirozenou pravomocí NRS by měl být také výběr soudních funkcionářů: „v soucáasnosti je zde rizike, že soudni funkcionári mohou být poplatni exekutivě. Proto by [jejich výběr] méla dèlat soudni rada; Systémově je chybné, že funkcionári json jmenováni exekutivou. Proto by méla existovat soudni rada".126

Soudci se na druhou stranu neshodli v tom, zda by NRS měla mít nějakou pravomoc v kárném řízení se soudci. Zde byli někteří respondenti skeptičtí a raději by ponechali kárné stíhaní soudců výlučně na obecných soudech (resp. kárných senátech). Na druhou stranu se ale respondenti z řad soudců shodli na tom, že NRS by měla zastupovat soudnictví na veřejnosti, tedy i v komunikaci s médii a veřejností: „Já vỉbec netoǔ̌ím po tom,

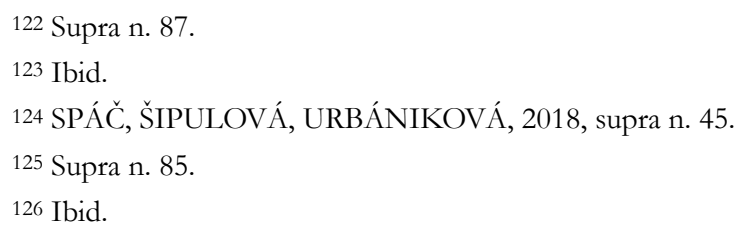


aby ta, pokud by se zrídila nèjaká nejuyšši rada soudnictví, mèla mocenské pravomoci. O to nejde. Jde o to, aby sjednocovala zájmy justice a bledala to společný [...] To, co jako je dìležité pro tu justici. "127 Dále by bylo důležité, aby NRS hodnotila stav soudnictví, což se podle jednoho z oslovených soudců v současnosti v důsledku absence NRS ,vuibec v ČR nedélá, protože $v$ soucasnosti by to dělala výkonná moc a to nejde, od nich to soudci nevezmou "128 Jako poslední okruh soudci zmínili pravomoc připomínkovat legislativu týkající se soudnictví, včetně rozpočtu, a to zejména po italském vzoru.

Takto nastavená NRS by podle soudců měla pozitivní dopad zejména na transparentnost soudnictví (komunikaci nejen s veřejností a médii, ale i ministerstvem) a na kontrolu jeho efektivity. Dále by zajistila lepší kontinuitu a know-how, umožnila vytvoření jednotné koncepce pro výběr soudců a promyšlení větších institucionálních reforem, které soudnictví čekají. ${ }^{129}$ Rovněž tak soudci očekávali, že by NRS pomohla justici více se otevřít vnějším vlivům, a to zejména v oblasti personálního obsazení. Na druhou stranu, jak již bylo uvedeno, i soudci preferující NRS přiznali, že její zrrízení s sebou nese jistá rizika, a byli si vědomi závislosti na personálním složení NRS. Také však zdůraznili, že „,každý model má své výhody a nevýhody, závisí to na kontextu, reáliich, neprenositelné zkeušenosti “130

\subsubsection{Očekávánípolitikè}

Obecně řečeno, většina oslovených politiků nebyla NRS nakloněna. Pouze jeden respondent považoval (slabou formu) NRS za vhodný model pro Českou republiku, a dva další uvedli, že zř́zení NRS si dokážou představit, pokud by klíčové slovo a odpovědnost zůstaly exekutivním orgánům. Tito respondenti se shodli na tom, že pokud by se nějaká NRS vytvořila, musela by být založená na paritním principu, s kompetencemi v personální oblasti - zejména co se týče výběru funkcionářŭ, rozhodně ale ne v oblasti fiskální. NRS by navíc fungovala pouze jako poradní hlas pro ministerstvo spravedlnosti. Stojí za zmínku, že v tomto směru se představy politiků, kteří připouštěli vznik NRS, nijak významně nelišily od ideálního modelu propagovaného soudci.

Celkem jsme identifikovali tři základní argumenty proti NRS: 1) politickou legitimitu a odpovědnost musí nést exekutivní orgán, jako je ministerstvo spravedlnosti; 2) současný systém je nastavený dobře, změny jsou nutné spíše v praktické úrovni; 3) zkušenosti ze zahraničí varují před nejvyššími radami soudnictví, nebot' NRS ingerence moci výkonné nezastaví a podle některých činí ovládnutí justice dokonce ještě snazším.

Mezi respondenty $z$ řad politiků tak převládaly skeptické a negativní postoje vůči NRS, přičemž většina $z$ nich se odvolávala na principy dělby moci. Zdůrazňovali, že řízení

\footnotetext{
127 Supra n. 92.

128 Ibid.

129 Zmíněné bylo především překreslení tzv. soudní mapy České republiky, tj. změna počtu a obvodů obecných soudů.

130 Supra n. 92.
} 
vyžaduje př́imou politickou legitimitu vzešlou $z$ voleb. Jeden $z$ respondentů například za ideální označil sdílení personálních kompetencí mezi mocí soudní a exekutivou, která by fungovala jako politická kontrola: „To si myslím, že by byl systém, který by [...] eliminoval různá nebezpeči, keterá plynou z. toho, že vybiraji predsedy soudu jenom politici anebo že je to pouze $v$ rukou soudcü. To je kombinovaný model jmenování, rozdèleni mezi politickou a justični jakoby moc

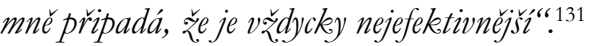

Část politiků se navíc shodovala na tom, že současný systém správy soudnictví funguje dobře, a to zejména díky nálezům Ústavního soudu o platech soudců nebo o zavedení časově omezeného mandátu soudních funkcionářù. ${ }^{132}$ Výhodou současného systému je, že „eliminuje rižiko, ̌̌e ho někedo ovládne"“"133

Politici uznávali, že NRS může mít pozitivní vliv na kontinuitu a jasné nastavení pravidel, nicméně její dopad na kvalitu justice na rozdíl od soudců zpochybňovali. „Já osobně si myslim, že neplati teže, že tam, kde je samospráva justice, tam prostě [justice] funguje lépe. Pokud by zde [samosprávní orgán] byl, já bych jeho pravomoce vnímal v personální úrovni, ale nemyslím si, že to je spasitelné a že by to mélo velký vliv na výkonnost justice v krátkodobém méritteu. Já si treba myslim, že vètši vliv na výkon justice maji třeba predsedové soudü."134

Dva z politiků také poukázali na to, že NRS by pouze subjektivně soudní moc uklidnila a dala soudcům pocit, že mají v rukou více pravomocí. NRS by však vůbec nedokázala vyřešit klíčové problémy, kterým aktuálně české soudnictví čelí, jako fragmentace (zejména v oblasti výběru soudců) a nedostatek kontinuity. Tyto problémy by se navíc podle politiků daly řešit jinými institucionálními modely a zejména posílením spolupráce mezi ministerstvem a předsedy soudů coby reprezentanty soudnictví. Respondenti byli toho názoru, že současný stav počítá s tím, že ministerstvo sdílí řadu kompetencí se soudci přes předsedy soudů, nicméně ti vnímají politiky a ministerské úředníky jako své nepřátele, nikoliv jako spojence.

Ústavni soud neprimo volal po zavedeni prvkì soudcovské samosprávy v okamžilku, kdy prostě ríkal, že hodnoceni soudcui v současném modelu správy justice neni možné... to je jeden prvek, kedy se volá po samosprávé. Drubý prvek je v prípadech, to se objevilo zas v nálezech ve véci platu soudcu, kdy Ústavni soud zmiňoval potrebu reprezentativního orgánu, který by soudcovskou moc

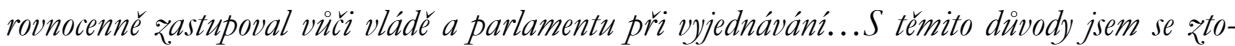
tožñoval. Ale dokážnu si predstavit, [...] i rèsené jiná než Ústavni soud naznačuje. Řěsení jiná $v$ tom smyslu, že nemusi být nutné zavedená soudcouská samospráva. A i tu rovnocennost soudni reprezentace sexekutivou víci vládè, víci parlamentu [...] lze docílit faktickými postupy a mechanismy komunikace. ${ }^{135}$

\footnotetext{
131 Rozhovor s politikem P3CZ ze dne 26. března 2018.

132 Srov. nález Ústavního soudu ze dne 14. řijna 2010, sp. zn. Pl. ÚS 39/08.

133 Supra n. 105.

134 Supra n. 131.

135 Supra n. 94.
} 
Konečně, podle politiků vývoj v sousedních středoevropských zemích naznačuje, že model NRS se neosvědčil v postkomunistickém prostředí, kde je stále mnoho vysoko postavených funkcionářu zatížených komunistickou minulostí nebo neformálními vzorci chování: „Ten prèedseda Nejvyššrího soudu mě prostě sám od sebe varoval prè tím, abychom něco takovébo zaváděli, že to prostě zpuisobuje jenom problémy. A že výhody to nemá žádné. "136. Soudní rady fungující na Slovensku, v Mad’arsku a v Polsku ukazují, že nejsou zárukami nezávislosti a nedokážou účinně odstínit zásahy exekutivy do soudní moci: „a zejména jsem nezaznamenal, že by to vedlo ke néjakému odstínèni soudcu od politických vlivư" " ${ }^{137}$

Spíše naopak, podle respondentů z rad politiků NRS s sebou často přináší zvýšení politizace, a to zejména když se kandidáti z řad soudců ucházejí o nominaci v NRS, zejména u politických navrhovatelů. Zde je nutno doplnit, že ač politici často poukazovali na to, že NRS nemusí zvýšit nezávislost justice, soudci, kteří NRS podporovali, také uváděli, že vztah mezi NRS a nezávislostí není prímý a že o její zřízení usilují z jiných, spíše pragmatických důvodů.

Lze tedy uzavřít, že podle většiny oslovených politiků rizika zřízení NRS daleko převyšují nad potenciálními prínosy. Krom toho, pokud by se model NRS ukázal jako defektní, jeho negativní důsledky pro nezávislost soudnictví by byly dalekosáhlé. Řada politiků se u NRS také obávala dalšího zapouzdření a uzavření justice do sebe. Ačkoliv politici připouští, že současný model správy soudnictví je v oblasti personální politiky nestabilní a fragmentovaný, zároveň podle nich tyto jeho vlastnosti jej činí odolnějším a méně náchylným k tomu, aby soudní moc mohla ovládnout jediná politická skupina.

\subsubsection{Očkávani právnikei}

U respondentů z řad právníků také převažovaly vưči NRS negativní postoje, které jsme seskupili do čtyř typových argumentů: 1) absence poptávky po NRS, 2) riziko dalšího zapouzdření justice, 3) negativní zkušenosti sousedních států. Právníci naopak viděli potenciální přínos v 4) odstínění současného vlivu předsedů soudů.

Co se týče prvního argumentu, absence poptávky, většina právníků se domnívala, že zřízení NRS není nezbytné, jelikož neodpovídá na současné problémy českého systému a ani mezi soudci neexistuje jednoznačná poptávka: „K čemu by byla? Maximálně by blokovala legislativní nápady v extrémních situacích. "138 Další z právníků také pochyboval o tom, nakolik jsou aktuální výzvy řešitelné přes NRS:

Je otázkea, co by mèla dèlat [NRS] a jestli je viobec zapotrebi. Protože pokud jde o takovou tu striktni státni správu ve smyslu správa budov, personálni politika [...] tak tam by justici nèjaký korektiv ze strany výkonné moci prospèl a neni dìvod se ho vz̨dávat [...] A prostě když.

\footnotetext{
136 Ibid.

137 Ibid.

138 Supra n. 90.
} 
ríkám, že se to zapouzdruje, tak nedává smysl veškerý vstupy zuenči odbourávat. A co se týče participace na procesu jmenováni soudcui, tak tam by [samospráva] své misto asi méla. Ale je otázkou, jestli na to potrebujeme institucionalizovanou radu soudnictví, anebo jestli se dá sábnout do rad soudcu bez, toho, aniž by vžnikla rada soudnictvi. ${ }^{139}$

Přitom většina oslovených, i když připustili možnost NRS, stále preferovala jiný systém správy: „u výbèru by to byla lepši alternativa, než co máme nyni, ale ideální je, aby výbèr rídila exekutiva a legislativa". ${ }^{140}$

Ve srovnání se soudci ale právníci nehodnotili současný systém správy soudnictví tak negativně. Problémy shledávali spíše $\mathrm{v}$ dostupnosti vhodných kandidátů pro výkon funkce soudce než v samotném systému výběru, což je podle nich důsledkem nekvalitního vzdělávání a uzavřenosti justice.

Podobně jako soudci, i právníci vnímali zapouzdřenost a nízkou kvalitu soudců jako problém justice, nicméně v otázce, zda by NRS tento problém vyřešila, měli blíže k politikům. NRS podle nich může vést k ještě výraznějšímu zapouzdření celého systému:

Velmi bych uvažoval o tom, jestli ta nejvyššr rada soudnictvi nemůže posilit zapouzdreni justice. A jestli ty prínosy, které ochráni justici pred nèjakými negativy ve smyslu nežádoucího ovlivñováni výkonnou mocí, šikana soudce, vytváreni vlivových koalic a tak podobnè, tak jestli nábodou ta rižika nejson ještě vétš̀i ${ }^{141}$

Jako třetí riziko se u respondentů objevoval důraz na negativní zkušenosti ze sousedních států. Právníci konkrétně poukazovali na to, že NRS s sebou nese daleko více rizik, než pozitiv:

Slovensko je ukázkou, že ani lepši institucionálni design nemusi fungovat. Treba zpuisob výbèru neni tak důležitý jako kvalita jednotlivých soudcü. Spiše qávisí na kvalitě právníkư, z nichž se vybirá. ${ }^{142}$

Často se proto objevoval argument, že „instituce json důležité, ale pouze pokud json dobre personálně obsazené“. ${ }^{143}$ Vznik NRS by „prinesl riziko, že soudci by dělali politiku“" ${ }^{144}$ nebo

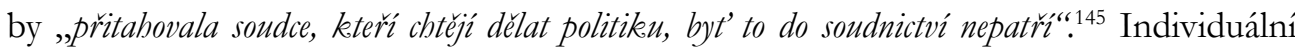
kvality jednotlivých soudců jim připadaly celkově důležitější než rozpravy o systémovém nastavení výběru.

Podobně jako soudci a politici, ani právníci neidentifikovali jako hlavní cíl existence NRS zvýšení nezávislosti soudců: „nezávislost neni dobrým argumentem. Politici tordí, že soudci

\footnotetext{
139 Rozhovor s právníkem L4CZ ze dne 14. března 2018.

140 Supra n. 90.

141 Supra n. 139.

142 Supra n. 95.

143 Rozhovor s právníkem L7CZ ze dne 18. července 2018.

144 Supra n. 90.

145 Rozhovor s právníkem L8CZ ze dne 15. května 2018.
} 
nemuizou být zcela nezávisli, proto $i$ soudci chodí na téma soudni rady s opatrným argumentem,

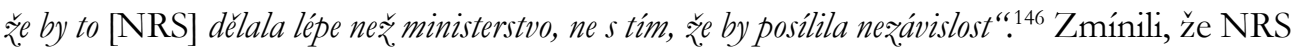
ani neodstíní útoky na soudnictví a ,není to garance vétš̌ stability "“ ${ }^{147}$

Pokud jde o potenciální pozitiva zř́ízení NRS, ti právníci, kteří vytvoření NRS připouštěli, také očekávali, že by mohla odstínit silný vliv předsedů krajských soudů, kteří jsou v současnosti vybíráni výkonnou mocí: „Smyslem té rady [soudnictví] je, aby dala nèjaký rozumný rámec obsazováni justice na základě pravidel, které definuje zákonodárce a ne predsedové krajskéch soudu a odstinila politický a hospodárskeý zájmy. " NRS i tak primárně jen vykonávala pravidla stanovená zákonodárcem a řešila systémové nastavení typu „kede je kolike personálu, kede by mèli sedèt a soudit soudci, č́m psát, atd. " ${ }^{449}$

Co se týče kompetencí a složení NRS, tato skupina právníků preferovala slabý model NRS s pravomocemi v personální oblasti (a naopak, rozhodně ne ve fiskálnî), založený na paritním členství a dostatečném zastoupení nesoudců. Podle právníků se ,nabizí, aby to bylo pestré" 150 a nesoudci by tak mohli zahrnovat nejen politiky, ale i ,státni zástupce, zastoupená by mèla být $i$ advokacie a akademická sféra". ${ }^{151}$ Třeba u výběru soudců jeden respondent uvedl, že by si „dovedl predstavit participaci profesních komor: advokátská, notárská, exekutorská. Dovedl bych si koneckonci prédstavit i participaci akademických pracovišt” ".152 Silně zastoupený byl názor, že rozhodnutí nestojí v rovině, zda NRS ano, nebo ne, ale jaké by NRS měla atributy a jak by byla obsazená: ,[vše] závisí na tom, v jaké podobě bychom

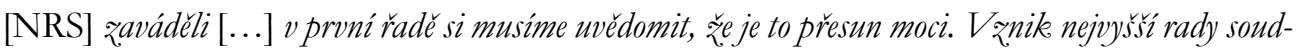
nictví je prèsun moci. Z jednoho mocenskébo centra, které máte na Vyšehradské 16, prèsunete tu moc na Nejvyšsí radu soudnictví. S tím jsou spojena všechna üskali" “.53

\subsubsection{Shrnutí}

Je zajímavé, že mezi soudci a politiky existuje velký průsečík v tom, jak by NRS měla být nastavená, a to i přesto, že většina politiků NRS odmítá. O aspektu NRS, kterému se v české debatě věnuje tolik prostoru, tj. jejímu složení, mezi našimi respondenty panovala vzácná shoda (Tabulka 3). Pokud by NRS měla vzniknout, většina zástupců tř́ skupin si NRS představovala jako paritní orgán. $V$ debatě však prozatím chyběly jiné otázky, které aktuálně rezonují v zahraničí. Jde zejména o to, do jaké míry by mělo být členství otevřené expertům, tj. právníkům, akademikům nebo státním zástupcům. Rovněž tak

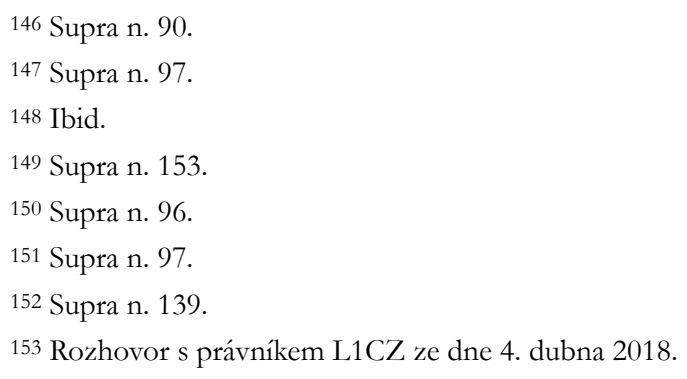


výrazně absentují úvahy o tom, koho má NRS vlastně zastupovat, jestli by členové NRS měli reprezentovat soudce, kteří je zvolili, nebo by měli tvořit nezávislý orgán správy soudnictví.

Tabulka 3: Představy respondentů o vhodném modelu NRS pro Českou republiku

\begin{tabular}{|c|c|c|c|}
\hline \multicolumn{4}{|c|}{ Ideální model NRS } \\
\hline & Soudci & Politici & Právníci \\
\hline Žř́zení & spíše ano & spíše ne & spíše ne \\
\hline Složení & $\begin{array}{l}\text { parita, spíše bez } \\
\text { soudních funkcionářů }\end{array}$ & $\begin{array}{l}\text { parita, bez soudních } \\
\text { funkcionár̆ù }\end{array}$ & $\begin{array}{l}\text { parita, bez soudních } \\
\text { funkcionář̀u }\end{array}$ \\
\hline $\begin{array}{l}\text { Kompetence } \\
\text { NRS }\end{array}$ & $\begin{array}{l}\text { personální, běžná } \\
\text { správa, hodnocení } \\
\text { kvality soudců, } \\
\text { připomínky k legislativě, } \\
\text { reprezentace } \\
\text { a komunikace navenek }\end{array}$ & $\begin{array}{l}\text { personální, běžná } \\
\text { správa, hodnocení } \\
\text { kvality soudců } \\
\text { připomínky k legislativě, } \\
\text { reprezentace } \\
\text { a komunikace navenek }\end{array}$ & $\begin{array}{l}\text { personální, běžná } \\
\text { správa, připomínky } \\
\text { k legislativě }\end{array}$ \\
\hline $\begin{array}{l}\text { Kompetence } \\
\text { MinS }\end{array}$ & $\begin{array}{l}\text { výběr funkcionářù, } \\
\text { kárná řízení, rozpočet }\end{array}$ & rozpočet & rozpočet \\
\hline
\end{tabular}

Zdroj: autoři

Z analýzy rozhovorů se tak zdá, že mnohem důležitější je otázka, jaké cíle by NRS měla plnit - od nichž by se pak měla odvíjet i debata o jejím nastavení. Jak jsme již zmínili, hodnoty, k jejichž posílení NRS obvykle v prohlášeních a mezinárodních dokumentech vede, v odpovědích našich respondentů spíše chyběly. Nezávislost soudnictví se objevila pouze u soudců, a to ještě velmi neprrímo. Politici a právníci se naopak spíše obávali zhoršení a větší míry politizace NRS, než je tomu u ministerstva spravedlnosti. Politici také poukazovali na negativní dopad na již vychýlené vztahy vnitřní nezávislosti soudců na předsedovi soudu.

Zatímco soudci přiznali, že model NRS je křehký, a netvrdili, že jde o systém výrazně odolnější vůči ingerencím moci výkonné, politici a právníci shledávali v ustanovení NRS spoustu rizik spojených s její možnou politizací. Často upozorňovali také na to, že v postkomunistických zemích se tento model projevuje jako disfunkční. ${ }^{154}$ Zajímavé je, že i když všichni respondenti identifikovali jako současný problém zapouzdření justice, navrhovali velmi odlišná řešení. Soudci se domnívali, že NRS zapouzdřenost odstraní, protože umožní, aby se na výběru soudců podíleli i zástupci jiných profesí. Politici a právníci se naopak obávali, že NRS by soudní moc ještě více izolovala.

154 Nejčastěji uváděli jako př́klad Slovensko. 
Zajímavý názorový střet se týkal také politické odpovědnosti. Zatímco většina soudců argumentovala, že předsedové nemají politickou odpovědnost za správu soudnictví, a proto ji ani nemohou z pověrení ministerstva de facto vykonávat, politici i právníci viděli negativa spíše v rovině přenosu kompetencí na NRS, pokud by hlavní politickou odpovědnost nadále neslo ministerstvo. I proto při úvahách o možném modelu NRS volili výlučně slabý model, v němž by NRS vysloveně fungovala jako poradní orgán ministerstva.

Celkově nejčastěji zmíněné očekávání spojené se zřízením NRS, zvýšení kvality soudců, kvality soudního rozhodování a celkové kvality řízení správy soudnictví, se objevilo mezi soudci i politiky. Politici však (společně s právníky) částečně zpochybňovali, zda je NRS k naplnění tohoto cíle nutná. Pokud je problémem selhávání ministerstva ve funkční rovině, tj. protože nemá dostatečné kapacity, finance a odbornost, řešením by podle politiků mohlo být svěření správy soudnictví jinému nezávislému, ale pořád exekutivnímu orgánu. Takové řešení by umožnilo lepší komunikaci mezi ministerstvem a předsedy soudů bez rizika politizace, a také snadnější řešení koncepčních otázek, které v současném systému nemůže nikdo uchopit:

... v okamřilku, kdy by v čele toho orgánu nebo úradu nebyl člen vlády, nebyl by ani vázán usnesenimi vlády, tím pádem celkově by mobla odpadnout ta politická rovina v okam̌̌iku, kdy by jeho misto bylo terminováno, tžn. naopak by byly reknème těxsisi podminky nebo obtižnèjsi podminky pro jeho odvoláni atd. atd. Tam si myslim, že by i ta justice to mobla vnimat o něco otevrenèjji. ${ }^{155}$

\section{Závěrem: Existuje mezi elitami konsenzus?}

Český diskurz zaznamenal již několik vln, v nichž se do hledáčku návrhy na zř́izení NRS vracely a následně zase upadaly v zapomnění. Ve skutečnosti však otázky spojené s jednotlivými aspekty soudcovské samosprávy prostupují každodenní realitu fungování soudů a diskutují se pořád, byt' to není třeba tolik vidět. Jak ukázala i naše analýza rozhovorů se zástupci soudců, politiků a právníků, debata o tom, jak nastavit správu soudnictví nekončí u černobílého rozhodnutí, zda NRS ustanovit, či nikoliv. Právě naopak. Klíčové problémy, které jsme v rozhovorech identifikovali, tedy netransparentní a fragmentovaný způsob výběru nových soudců, př́liš silné postavení předsedů soudů či absence vize ve způsobu, jakým soudnictví řídí ministerstvo spravedlnosti, to všechno jsou otázky bezprostředně související se soudcovskou (samo)správou a v zásadě nezávislé na konkrétním modelu nejvyšší rady soudnictví.

V tomto článku jsme reagovali na výzvu Michala Bobka, který v roce 2015 konstatoval absenci hlubšího akademického diskurzu o povaze a účelu NRS, ${ }^{156}$ a předložili detailní

\footnotetext{
155 Respondent jako př́klad uváděl potřebu regulace etického soudcovského jednání zejména ve vztahu k pedagogickým, autorským a jiným mimopracovním aktivitám soudců. Rozhovor s politikem P8CZ ze dne 15. listopadu 2018.

156 BOBEK, 2015, supra n. 26.
} 
konceptuální analýzu postojů zástupců soudců, politiků a právníků ke zř́zení NRS. Našim cílem přitom bylo nejen zmapovat podporu ustanovení NRS, ale také lépe strukturovat argumenty a hlavní problémy, které elity ve fungování správy soudnictví vnímají. Rozklíčování důvodů, které vedou tyto aktéry ke snaze o změnu systému, je jádrem jakékoliv budoucí úspěšné reformy správy soudnictví. Skromně však také doufáme, že do celé debaty vneseme více světla a poznání postojů dotčených profesních skupin.

V článku jsme proto položili otázku, zda zástupci z řad soudců, politiků a právníků podporují založení NRS, jakou by podle nich měla mít podobu a jaké pojí s jejím vytvořením očekávání. Ve srovnání s cíli deklarovanými v mezinárodních dokumentech stojî současná česká debata o NRS na převážně pragmatických argumentech. Dva klíčové kritické body, na kterých se překvapivě shodli soudci i politici, byly 1) kritika stávajícího ministerského modelu, resp. způsobu, jakým ministerstvo spravedlnosti správu vykonává, a 2) neúměrné posilování předsedů soudů, na něž ministerstvo mnohé kompetence neformálně deleguje.

Oba problémy mají dopad na dělbu moci a přerozdělení kompetencí mezi soudci a politiky. Soudci vidí soudy jako nezávislé a důvěřují jim, nicméně ministerstvo spravedlnosti podle nich výkon správy soudnictví nezvládá a nedokáže produkovat dlouhodobá řešení a koncepční vize. Soudcům vadí, že chyby na straně ministerstva vedou $\mathrm{k}$ př́lišnému zatížení předsedů soudů. Neformální delegování správy na předsedy podle soudců vede ke třem negativním jevům: (1) ke zdvojení rolí a následnému oslabení vnitřní nezávislosti řadových soudců na předsedech soudů, (2) k fragmentaci systému správy soudnictví a (3) ke vzniku odpovědnosti za oblasti, které stojí mimo specializaci předsedů - jako třeba velká finanční rozhodnutí spojená se správou budov. Většina dotazovaných soudců vidí odpověd' právě ve zrrízení samosprávného orgánu, ideálně NRS, byt' jejich hlas není zcela jednotný. NRS vnímají jako platformu pro jednání s ostatními složkami státní moci. Shodují se na tom, že NRS musí mít kompetence v personální oblasti (výběr, kariérní postup a kárná stíhání soudců) a zajistit minimálně paritu soudních a nesoudních členů. Podle politiků jsou kontury současného modelu správy soudnictví nastaveny dobře. Systém je sice fragmentovaný, ale díky tomu dokáže garantovat nezávislost soudů a odrazit pokusy o jejich ovládnutí. Přesto politici vnímají nedostatky spočívající v pasivitě ministerstva spravedlnosti. Podobně kriticky se vyjadřovali na adresu postavení předsedů soudů, nicméně vinu viděli ve vzájemné dynamice. Model delegace podle politiků počítá s tím, že předsedové jsou prodlouženou rukou ministerstva. Ti se tak však necítí ani nechovají. Z pragmatických (nedostatek odbornosti) i normativních důvodů (dělba moci) by předsedům přiznali jen personální pravomoci ovlivňující kariérní postup soudců. Přespř́liš kompetencí ponechaných na předsedech soudů totiž podle nich vede ke fragmentaci a zapouzdření soudní moci.

Část politiků by dokázala zrrízení slabého modelu NRS připustit, pokud by kontury celého systému nadále nastavovalo ministerstvo. Politici zdůrazňovali, že soudci se nesmí dostat 
do pozice, v níž by byli nuceni vyjednávat s exekutivou - proto jim např́íklad nelze svěřit pravomoci v rozpočtové oblasti. NRS podle politiků sama o sebe koncepční problémy českého soudnictví nevyřeší, vše závisí na tom, jaké by bylo její složení, kdo by členy vybíral, nebo jaké by měla pravomoci. Navíc k řešení největších výzev, na nichž se shodli se soudci (fragmentovaný výběr soudců), ani není potřebná. Odmítání NRS politici běžně opírali i o snadné zneužití NRS k ovládnutí justice v okolních evropských zemích. $\mathrm{Na}$ neschopnost ministerstva spravedlnosti vykonávat správu soudnictví poukazovali i někteří právníci. Ve srovnání se soudci a politiky se však zaměřovali na praktičtější problémy, jako je uzavřenost soudnictví, kvalita soudního rozhodování a kvalita soudců. Tyto otázky však viděli propojené spíše s nastavením systému vzdělávání než s koncepcí správy soudnictví. Odlišný úhel pohledu se objevil v tom, jak právníci problematizovali vnitřní nezávislost soudců - kterou konstatovali i v de facto rovině (tedy nikoliv jako pouhou možnost do budoucna). Na rozdíl od soudců se právníci domnívali, že tyto problémy změna ministerského modelu na NRS nevyřeší. Podobně jako politici se obávali, že NRS s sebou nese více rizik než pozitiv.

$\mathrm{V}$ analýze úvah respondentů o eventuálním složení NRS nás překvapil ještě jeden moment. Respondenti se zpravidla zabývali složením a obsazením NRS (poměrem soudců a nesoudců), nicméně opomíjeli kreační pravomoc aktérů, kteří by soudce a nesoudce do NRS vybírali. Respondenti tak téměř bez výjimky pracovali s představou, že soudcovští členové NRS by automaticky reprezentovali zájmy soudnictví, bez ohledu na to, zda byli do NRS vybráni mocí výkonnou nebo mocí soudní, a nesoudci by zase hájili zájmy exekutivy. ${ }^{157}$ Otázka, kdo by měl vybírat členy NRS v České republice a koho by tito členové měli zastupovat, tak překvapivě stojí stále na okraji odborného diskurzu, a to i přes to, že na finální podobu a jednání NRS právě z hlediska dělby moci může mít zásadní dopad.

Rámcové problémy soudnictví, které respondenti identifikovali a na kterých panovala víceméně shoda (překvapivě zejména mezi soudci a politiky), vybízejí také k otázce, zda je NRS opravdu jediným možným řešením a zda by pro stávající systém správy soudnictví nebylo prospěšnější, pokud by se dotčení aktéři oprostili od binární debaty, zda NRS ano, či ne, a namísto toho hledali cestu, jak identifikované nedostatky odstranit. Vzácným pozorováním, které vyplynulo z analýzy rozhovorů, je totiž zjištění, že soudci, politici i právníci vnímají ve fungování soudnictví velmi podobné výzvy a problémy.

\footnotetext{
157 Tento pohled je navíc $\mathrm{v}$ rozporu se zkušeností mnohých zemí, $\mathrm{v}$ nichž přetrvaly nepřímé politické vlivy a klientelistické sítě mezi politiky a soudci v NRS. K tomu srov. např́ḱlad situaci na Slovensku (SPÁČ, ŠIPULOVÁ, URBÁNIKOVÁ, 2018, supra n. 45), v Polsku (ŚLEDZIŃSKA-SIMON, Anna. The Rise and Fall of Judicial Self-Government in Poland: On Judicial Reform Reversing Democratic Transition. German Law Journal, 2018, roč. 19, č. 7, s. 1839-1870) anebo ve Španělsku (TORRES PERÉZ, Aida. Judicial Self-Government and Judicial Independence: the Political Capture of the General Council of the Judiciary in Spain. German Law Journal, 2018, roč. 19, č. 7, s. 1839-1870).
} 
Zřízení slabého modelu NRS, na němž existuje jistý konsenzus, má určitě potenciál odstranit fragmentaci výběru soudců. Doposud představené návrhy však nepracovaly ani s výše zmíněným problémem volitelů odpovědných za výběr členů NRS, ani s problémem zapouzdření justice, který vnímaly stejně negativně všechny elity. Rovněž tak současná debata neposkytuje řešení na problematické postavení a velké pravomoci předsedů soudů od krajské úrovně nahoru. Tato otázka přitom snad ani nemůže být aktuálnější. Jen v roce 2020 došlo k obměně na Vrchním soudu v Praze a pětici z osmi křesel předsedů krajských soudů, a to v těsném sledu poté, co se vyměnil předseda Nejvyššího soudu a předseda Vrchního soudu v Olomouci, a těsně předtím, než se bude vybírat nový předseda Nejvyššího správního soudu. České soudnictví tak v průběhu necelých dvou let dozná téměř kompletní obměnu na klíčových funkcionářských postech, což v kombinaci s modelem, kdy ministerstvo spravedlnosti vykonává správu právě přes předsedy soudů, poskytuje současné exekutivě nebývalý vliv. Zkušenosti z jiných zemí se silně zakořeněným hierarchickým kariérním modelem soudnictví navíc naznačují, že institucionální změny samy o sobě nedokážou odstranit vliv předsedů soudů dovnitř justice, aniž by souběžně doznaly změny profesní normy a (sebe)reflexe role soudců. ${ }^{158}$

$\mathrm{Na}$ nejpalčivější problémy českého soudnictví neposkytuje řešení ani stávající novela zákona o soudech a soudcích z pera ministerstva spravedlnosti připravená ve spolupráci s předsedy krajských soudů. Důkazem je třeba poslední návrh změny výběru soudců, ${ }^{159}$ který zcela ignoruje volání po větší názorové pluralitě a prostupnosti mezi právnickými profesemi. Stávající návrh jde přesně opačným směrem. Posiluje totiž socializaci velmi mladých právníků uvnitř soudnictví, a tím možnost zástupců jiných právnických profesí ucházet se o funkci soudce výrazně komplikuje. Do jisté míry lze říci, že i přes četné kulaté stoly $\mathrm{k}$ této problematice konečný návrh novely zákona o soudech a soudcích nereflektuje názory nejen řady soudců, ale i obavy politické elity a praktikujících právníků, že české soudnictví se uzavírá do sebe a tím přichází o kvalitu.

\footnotetext{
158 POPOVA, 2020, supra n. 9.

159 Poslanecká sněmovna, sněmovní tisk 630, novela zákona o soudech a soudcích. Dostupné z: https:// www.psp.cz/sqw/text/historie.sqw?o $=8 \& T=630$
} 